http://dx.doi.org/10.18778/1509-877X.03.03

\title{
MAŁŻEŃSTWO A ZWIĄZKI PARTNERSKIE W ŚWIETLE WYBRANYCH REGULACJI POLSKIEGO PRAWA PODATKOWEGO
}

Streszczenie. Artykuł poświęcony jest problematyce pozycji małżeństwa na gruncie wybranych regulacji polskiego prawa podatkowego w stosunku do tzw. związków partnerskich. Autor wykazał, że w świetle art. 18 Konstytucji Rzeczypospolitej Polskiej małżeństwo to związek kobiety i mężczyzny (związek monogamiczny osób o odmiennej płci), znajdujący się pod ochroną i opieką Rzeczypospolitej Polskiej i stanowiący, tzw. samoistną wartość konstytucyjną. Wywieść z tego należy, że także w obszarze polskiego prawa podatkowego brak jest podstaw prawnych do zrównania związków partnerskich (hetero- lub homoseksualnych) z małżeństwem. Dlatego tylko i wyłącznie małżeństwo korzysta z preferencji podatkowych, ponieważ ustawodawca preferuje je jako podstawę stosunków rodzinnych w przeciwieństwie do związków partnerskich, stanowiących wyłącznie kategorię stanów faktycznych a nie instytucję prawną. Ponadto zdaniem Autora małżeństwo potrzebuje pilnego i kompleksowego wsparcia systemowego, $\mathrm{w}$ tym również podatkowego, ponieważ z małżeństwem powinno być jak z przyzwoitością - może się nie opłaca w sensie ekonomicznym, ale warto je wspierać i wspomagać, np. „mechanizmami podatkowoprawnymi”.

Słowa kluczowe: małżeństwo, konkubinat, związki partnerskie, prawo podatkowe, podatki, preferencje podatkowe

* Dr, Adiunkt w Katedrze Prawa Podatkowego na Wydziale Prawa i Administracji Uniwersytetu Łódzkiego. 


\section{UWAGI WPROWADZAJĄCE}

Punktem wyjścia dla całego opracowania jest ustalenie pozycji małżeństwa przede wszystkim w świetle unormowań Konstytucji Rzeczypospolitej Polskiej ${ }^{1}$, w tym m.in. regulacji zawartych w preambule, a odnoszących się do osób wierzących w Boga i mających pełne prawo dążyć do tego, aby ustawy (w tym także podatkowe) były zgodne $\mathrm{z}$ ich moralnością.

Główne pytanie, jakie stawia autor w publikacji brzmi: czy związki partnerskie ${ }^{2}$ powinny korzystać $\mathrm{z}$ preferencji podatkowych, biorąc pod uwagę, że ich cechą charakterystyczną jest faktyczny, a nie prawny charakter $^{3}$. W artykule dokonano analizy tejże materii, m.in. na gruncie instytucji wspólnego opodatkowania małżonków w podatku dochodowym od osób fizycznych ${ }^{4}$, zwolnienia z art. 4a ustawy o podatku od spadków i darowizn ${ }^{5}$ oraz instytucji domniemanego pełnomocnika na gruncie Ordynacji podatkowej $^{6}$. Rozważania podjęte w opracowaniu obejmują również zagadnienia związane ze skutkami prawnymi stosowania art. $111 \$ 3$ o.p., który nakłada na członków rodziny ( $w$ tym także na osoby pozostające w faktycznym pożyciu) odpowiedzialność za zaległości podatkowe podatnika.

Pomimo, że ramy publikacji nie pozwalały na wyczerpujące ukazanie kontrowersji teoretycznoprawnych wiążących się z podjętym tematem, poruszane rozważania mają jeszcze jedno istotne znaczenie - są kolejnym głosem - na „pustyni podatkowej” o stworzenie optymalnej prorodzinnej roli państwa, w której małżeństwo stanowić będzie kamień węgielny.

${ }^{1}$ Ustawa z dnia 2 kwietnia 1997 r. Konstytucja Rzeczypospolitej Polskiej, Dz.U. z 1997 r. Nr 78, poz. 483 ze zm.; dalej: Konstytucja RP.

${ }^{2}$ Przez termin związek partnerski, który autor przyjmuje na potrzeby niniejszej publikacji, rozumie związki zarówno o charakterze hetero-, jak i homogenicznym, które cechuje nie tylko niejednolitość postaci, w jakich one obecnie funkcjonują, ale i wielość pojęć na ich określenie np. związek nieformalny, związek osób pozostających w konkubinacie, małżeństwo na próbę, osoby żyjące w tzw. układzie, związek osób pozostających we wspólnym pożyciu - por. wyrok WSA w Poznaniu z dnia 8 grudnia 2011 r., I SA/Po 585/11, CBOSA.

${ }^{3}$ Por. B. Brzeziński, J. Jezierski, Konkubinat a polskie prawo podatkowe, „Nowe Prawo" 1990, nr 4-6, s. 91 i nast.

${ }^{4}$ Ustawa z dnia 26 lipca 1991 r. o podatku dochodowym od osób fizycznych, tekst jednolity: Dz.U. z 2018 r., poz. 200 ze zm.; dalej: u.p.d.o.f.

${ }^{5}$ Ustawa z dnia 28 lipca 1983 r. o podatku od spadków i darowizn, tekst jednolity: Dz.U. z 2018 r., poz. 644 ze zm.; dalej: u.p.s.d.

${ }^{6}$ Ustawa z dnia 29 sierpnia 1997 r. Ordynacja podatkowa, tekst jednolity: Dz.U. z 2018 r., poz. 800 ze zm.; dalej: o.p. 
2. Istota ma£żeństwa W ŚWietle Konstytucji Rzeczypospolitej Polskiej i Pisma ŚWiętego a status zWiązKów PARTNERSKich

W świetle art. 18 Konstytucji Rzeczypospolitej Polskiej in principio małżeństwo to „związek kobiety i mężczyzny [...] znajdujący się pod ochroną i opieką Rzeczypospolitej Polskiej"”.

Przepis art. 18 Konstytucji RP jest wyrazem realizacji zasady ochrony małżeństwa, rozumianego jako związku kobiety i mężczyzny, a więc związku tworzącego więzi prawne jedynie między dwiema osobami różnej płci, gdyż monogamiczne małżeństwo kobiety i mężczyzny stanowi samoistną wartość konstytucyjną, którą ustawodawca ma obowiązek

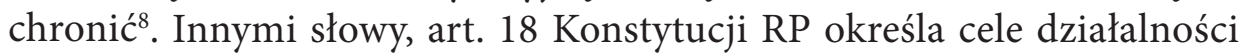
organów władzy publicznej, ponieważ z jednej strony, stanowi dyrektywę interpretacyjną pozostałych norm konstytucyjnych i ustawowych nakazującą najpełniejszą realizację zasady ochrony małżeństwa, a z drugiej pełni rolę normy programowej ${ }^{9}$. Również w orzecznictwie Trybunału Konstytucyjnego utrwalił się pogląd, że małżeństwo (związek osób o odmiennej płci) to podstawowa i naturalna komórka społeczna wyznaczona przez szereg przepisów ustawy zasadniczej ${ }^{10}$, np.: preambułę, czy też artykuły: 33, 47, 48, 53 ust. 3, 71. Tym samym, małżeństwo - jako związek kobiety i mężczyzny - w myśl regulacji art. 18 Konstytucji RP uzyskało odrębny status konstytucyjny, a jego zmiana byłaby możliwa jedynie przy zachowaniu rygorów trybu zmiany Konstytucji RP, określonych w art. 235 tego aktu' ${ }^{11}$. Dodatkowo należy zauważyć, że przyjęcie stanowiska, że ustrojodawca wskazał w Konstytucji odmienność płci jako konstytutywny wyznacznik małżeństwa znajduje ponadto uzasadnienie w art. 1 Kodeksu rodzinnego i opiekuńczego ${ }^{12}$, w którym ustawodawca

${ }^{7}$ Oznacza to, że „tylko związek kobiety i mężczyzny jest prawnie uznawany przez państwo i jako taki korzysta z ochrony i opieki Rzeczypospolitej” - wyrok TK z dnia 25 lipca 2013 r., P 56/11, Lex/el; W. Skrzydło, Konstytucja Rzeczypospolitej Polskiej. Komentarz 2013, Lex/el; wyrok TK z dnia 18 maja 2005 r., K 16/04, Lex/el.

${ }^{8}$ Wyrok TK z dnia 11 maja 2011 r., SK 11/09, Lex/el.

${ }_{9}^{9}$ Wyrok TK z dnia 3 grudnia 2013 r., P 40/12, Lex/el; wyrok TK z dnia 11 kwietnia 2006 r., SK 57/04, Lex/el.

${ }^{10}$ Wyrok TK z dnia 12 kwietnia 2011 r., SK 62/08, Lex/el.

${ }^{11}$ Wyrok TK z dnia 11 maja 2005 r., K 18/04, Lex/el; postanowienie SA w Katowicach z dnia 13 czerwca 2017 r., V ACz 495/17, Lex/el.

${ }^{12}$ Ustawa z dnia 25 lutego 1964 r. Kodeks rodzinny i opiekuńczy, tekst jednolity: Dz.U. z 2017 r., poz. 682 ze zm.; dalej: k.r.o. 
określił przesłanki zawarcia małżeństwa. Przy okazji warto zwrócić uwagę, że „doprecyzowanie w art. 18 pojęcia małżeństwa o zwrot „jako związek kobiety i mężczyzny" ma ułatwiać pełnienie przez ten przepis roli wzorca kontroli konstytucyjności prawa" ${ }^{13}$. Ponadto, z art. 18 Konstytucji RP „płynie zakaz” nadawania związkom partnerskim charakteru małżeństwa $^{14}$, gdyż „użycie liczby pojedynczej wyraźnie wskazuje, że chodzi tu o związek jednej kobiety i jednego mężczyzny”"15, stanowiąc „odrzucenie związków jednopłciowych, związków poligamicznych oraz związków wielu osób obojga płci (tzw. komuny)"16. Należy także podkreślić, że objęcie małżeństwa ochroną i opieką wskazuje, że tylko taka „komórka społeczna” może korzystać z materialnej i instytucjonalnej pomocy państwa, tworząc tzw. heteronormatywny model społeczeństwa ${ }^{17}$.

Prawodawca $\mathrm{w}$ preambule ${ }^{18}$ do ustawy zasadniczej expressis verbis nawiązuje do Boga m.in., w słowach: „my, Naród Polski - wszyscy obywatele Rzeczypospolitej, zarówno wierzący w Boga będącego źródłem prawdy, sprawiedliwości, dobra i piękna [...]”; „za kulturę zakorzenioną w chrześcijańskim dziedzictwie Narodu”, czy „w poczuciu odpowiedzialności przed Bogiem”. Choć preambuła do Konstytucji RP z 1997 r. jest $\mathrm{w}$ wielu miejscach niekonsekwentna w swej treści, to bez wątpienia

${ }^{13}$ W. Borysiak, Komentarz do art. 18 Konstytucji RP, [w:] M. Safjan, L. Bosek (red.), Konstytucja RP. Tom I. Komentarz do art. 1-86 (2016), Legalis/el.

${ }^{14}$ P. Winczorek, Komentarz do Konstytucji Rzeczypospolitej Polskiej z dnia 2 kwietnia 1997 r., Warszawa 2008, s. 54.

${ }^{15}$ B. Banaszak, Konstytucja Rzeczypospolitej Polskiej. Komentarz 2012, Legalis/el.

${ }^{16}$ B. Banaszak, M. Zieliński, Konstytucyjne i ustawowe pojęcie rodziny, „Monitor Prawniczy” 2014, nr 7, s. 34.

${ }_{17}$ G. Kowalski, Założenia prawa rodzinnego $w$ świetle Konstytucji Rzeczypospolitej Polskiej, [w:] P. Kasprzyk, P. Wiśniewski (red.), Prawo rodzinne w dobie przemian, Lublin 2009, s. 50.

${ }^{18}$ Preambuła (tzw. uroczysty wstęp), który nie jest obligatoryjnym elementem każdego aktu normatywnego, a jedynie stosowanym w sytuacji, gdy ustawodawca chce wyraźnie określić cele danej regulacji prawnej, dostarcza wskazówek, co do zasad interpretacji poszczególnych artykułów normowanych w analizowanym akcie prawym i ma wiążące znaczenie dla jego wykładni, ale przede wszystkim wyjaśnia cel i ducha wydanego aktu - wyrok WSA w Opolu z dnia 5 lutego 2004 r., II SA/Wr 318/01, CBOSA; W. Skrzydło, Konstytucja..., Lex/el; B. Banaszak, Konstytucja..., Legalis/el; M. Stefaniuk, Preambuła do Konstytucji RP z 2 kwietnia 1997 roku w orzecznictwie Trybunału Konstytucyjnego, „Annales Universitatis Mariae Curie-Skłodowska Lublin-Polonia, Sectio g” 2003/2004, vol. L/LI, s. 203 i nast. 
stanowi invocatio Dei i wartości chrześcijańskich ${ }^{19}$ i nic w tym dziwnego, skoro została uchwalona przez naród, którego kultura jest przeniknięta chrześcijaństwem ${ }^{20}$.

Według Biblii (Pisma Świętego), które jest sui generis „Konstytucją Chrześcijan” „małżeństwo ustanowione przez Boga, potwierdzone przez Chrystusa i apostołów - małżeństwo w sensie biblijnym - to legalny i trwały związek mężczyzny i kobiety" ${ }^{21}$. Oznacza to, że małżeństwo według „Prawa Bożego”: jest związkiem trwałym ${ }^{22}$, co do zasady dozgonnym i nierozerwalnym ${ }^{23}$. Innymi słowy, według Biblii małżeństwo jest instytucją Boskiego pochodzenia, ponieważ to Bóg stworzoną przez siebie parę ludzką związał węzłami wzajemnej miłości, świętego szacunku i obowiązku ${ }^{24}$ w pierwszy związek małżeński ${ }^{25}$ i to związek monogamiczny ${ }^{26}$. Prowadzi to do wniosku, że w Piśmie Świętym propagowana jest koncepcja jednego mężczyzny i jednej kobiety, którzy złączeni są świętym węzłem małżeńskim, jako komplementarność płci ${ }^{27}$.

Podsumowując, Pismo Święte opowiada się za małżeństwem - jako związkiem kobiety i mężczyzny - oraz nierozerwalnością tego węzła ${ }^{28}$.

${ }^{19} \mathrm{P}$. Bała, Invocatio dei w Konstytucji RP z 2 kwietnia 1997 r. w perspektywie porównawczej i historycznej, http://www.bibliotekacyfrowa.pl/Content/39049/016.pdf.

20 T. Jaklewicz, Konstytucyjne prawa wierzacych, https://www.gosc.pl/doc/2142934. Konstytucyjne-prawa-wierzacych.

${ }^{21}$ Z. Łyko, Nauki Pisma Świętego, Warszawa 1989, s. 588.

22 „Tak więc już nie są dwoje, lecz stanowią jedno, co zatem Bóg złączył, człowiek niech nie rozdziela" - Ewangelia wg św. Mateusza 19.6, [w:] Biblia Ekumeniczna, Towarzystwo Biblijne w Polsce, Warszawa 2017, s. 1593; dalej: Biblia Ekumeniczna.

${ }^{23}$ Są tylko dwa powody ustania związku małżeńskiego akceptowane przez Pismo Święte:

a) śmierć jednego z małżonków - List do Rzymian 7.2,

b) rozwód - ale wyłącznie z powodu niewierności (nierządu, cudzołóstwa) jednego z małżonków - Ewangelia wg św. Mateusza 5.32 - Biblia Ekumeniczna, s. 1813 i 1567.

${ }^{24}$ Także świętość małżeństwa potwierdził Jezus Chrystus, np. swoją obecnością na weselu w Kanie Galilejskiej (Ewangelia Św. Jana 2.1-11). Również według Listu do Hebrajczyków 13.4 „Do małżeństwa niech wszyscy odnoszą się z szacunkiem, a pożycie małżeńskie niech będzie nieskalane, gdyż Bóg osądzi rozpustników i cudzołożników" - Biblia Ekumeniczna, s. 1709-1710 i 1955.

${ }^{25}$ Z. Łyko, Nauki..., s. 586.

${ }^{26}$ Ibidem, s. 588.

${ }^{27}$ Księga Rodzaju (I Mojżeszowa) 2.22-23 - Biblia Ekumeniczna, s. 31.

${ }^{28}$ Por. S. Świaczny, Nierozerwalność małżeństwa a rozwiązanie małżeństwa naturalnego w prawie kanonicznym, Katowice 2004, s. 76. 
Zatem biblijny koncept małżeństwa obrazuje jedność między dwiema osobami (kobietą i mężczyzną), na wzór relacji jedności Chrystusa z Jego Kościołem. Wywieść z tego należy, że związki partnerskie, „poza brakiem zgodności z naturą, nie odpowiadają zamysłowi Stwórcy"29.

\section{3. ŁĄCZNE OPODATKOWANIE MAŁŻONKÓW NA GRUNCIE PODATKU DOCHODOWEGO OD OSÓB FIZYCZNYCH}

W świetle art. 6 ust. 1 u.p.d.o.f. małżonkowie podlegają odrębnemu opodatkowaniu od osiąganych przez nich dochodów. Jednakże małżonkowie mogą być opodatkowani łącznie od sumy swoich dochodów, po spełnieniu przewidzianych $\mathrm{w}$ art. 6 ust. 2 i ust. 3 u.p.d.o.f. przesłanek ${ }^{30}$. Nie ulega jednak wątpliwości, że podatnikiem jest każdy z małżonków ${ }^{31}$, a instytucja wspólnego opodatkowania małżonków to wyłącznie swoisty „zabieg techniczny, mający na celu obniżenie należności podatkowej, a nie zmianę płaszczyzny podmiotowej"32.

${ }^{29}$ S. Biel, K. Biel, Kobiety między miłością a zdradą. Medytacje biblijne, Kraków 2012, s. 12; Księga Kapłańska (III Księga Mojżeszowa) 18.22 i 20.13; List św. Pawła do Rzymian 1.26-27; Pierwszy List św. Pawła do Koryntian 6.9-10 - Biblia Ekumeniczna, passim.

${ }^{30}$ Szerzej A. Kostecki, Podmiotowość podatkowa małżonków, „Państwo i Prawo” 1965, nr 1, s. 63 i nast.; T. Dębowska-Romanowska, O pojęciu i skutkach „wniosku wyrażonego we wspólnym zeznaniu rocznym" o łączne opodatkowanie małżonków - w rozumieniu art. 6 ust. 2 ustawy o podatku dochodowym od osób fizycznych, [w:] Regulacje prawno-podatkowe i rozwiazania finansowe. Pro publico bono. Księga jubileuszowa Profesora Jana Głuchowskiego, Toruń 2002, s. 53; wyrok WSA w Warszawie z dnia 29 stycznia 2013 r., III SA/Wa 2932/12, CBOSA; Z. Kukulski, D. Strzelec, Prawo podatkowe, Warszawa 2012, s. 133-135; I. Nowak, Zwolnienie dla osób najbliższych na podstawie art. 4 a ustawy o podatku od spadków i darowizn w świetle orzecznictwa i poglądów doktryny, „Toruński Rocznik Podatkowy" 2012/el; I. Nowak, Wspólne opodatkowanie małżonków na gruncie podatku dochodowego od osób fizycznych - postulaty de lege lata i de lege ferenda, [w:] B. Kucia-Guściora, M. Münnich, A. Zdunek, Stanowienie i stosowanie prawa podatkowego w Polsce. Sankcje i preferencje w prawie podatkowym, Lublin 2015, s. 219 i nast.; wyrok NSA z dnia 8 grudnia 2016 r., II FSK 3319/14, CBOSA.

${ }^{31}$ A. Nykiel, Podmiotowość podatkowoprawna. Wybrane zagadnienia, „Państwo i Prawo" 2000, nr 3, s. 62; M. Goettel, Niektóre aspekty wspólnego opodatkowania małżonków, „Przegląd Podatkowy” 2001, nr 4, s. 29.

32 R. Kolendowicz, Podmiotowość podatkowoprawna przy konstrukcji łącznego opodatkowania dochodów matżonków, „Kwartalnik Prawa Podatkowego” 2012, nr 4, s. 105; A. Bartosiewicz, Pojęcie podatnika w świetle przepisów Ordynacji podatkowej, „Kwartalnik Prawa Podatkowego" 2009, nr 3-4, s. 18. 
Regulacja prawna ustawy o podatku dochodowym od osób fizycznych polegająca na możliwości złożenia wspólnego zeznania rocznego ${ }^{33}$, uzasadniona jest charakterem małżeństwa (rodziny) ${ }^{34}$, który przejawia się m.in. tym, że stanowi ono ekonomiczną jednośćc ${ }^{35}$. Pomimo, że podstawową zasadą opodatkowania podatkiem dochodowym od osób fizycznych jest obciążenie tą daniną publiczną dochodów uzyskiwanych przez indywidualne osoby $^{36}$, to normodawca przewiduje wyjątki od ogólnych reguł opodatkowania, do których zaliczyć można uwzględnienie przy ustalaniu wymiaru podatku sytuacji rodzinnej podatnika, a w konsekwencji jego zdolności płatniczej ${ }^{37}$, czego wyrazem jest szczególny tryb rozliczania się małżonków ${ }^{38}$.

Sposób obliczania podatku dochodowego od osób fizycznych pozwala małżonkom odnieść korzyści ${ }^{39}$, jeśli jeden z nich nie osiąga dochodów w ogóle, bądź jego dochody są relatywnie niewielkie, drugi zaś małżonek zarabia na tyle dużo, że jego dochody są opodatkowane progresywnie ${ }^{40}$.

${ }^{33}$ Art. 6 ust. 2 u.p.d.o.f.

${ }^{34}$ Wniosek o łączne opodatkowanie dochodów małżonków, między którymi istniała w roku podatkowym wspólność majątkowa, może być także złożony przez podatnika, który:

1) zawarł związek małżeński przed rozpoczęciem roku podatkowego, a jego małżonek zmarł w trakcie roku podatkowego,

2) pozostawał w związku małżeńskim przez cały rok podatkowy, a jego małżonek zmarł po upływie roku podatkowego przed złożeniem zeznania podatkowego - art. 6a ust. 1 u.p.d.o.f.

${ }^{35}$ Por. wyrok WSA w Kielcach z dnia 18 sierpnia 2011 r., I SA/Ke 321/11, CBOSA; I. Nowak, Obowiązek alimentacyjny a prawo podatkowe - wybrane aspekty, „Toruński Rocznik Podatkowy" 2015/el; H. Litwińczuk, Opodatkowanie rodziny, Warszawa 1989, s. 18 i nast.

${ }^{36}$ Szerzej W. Wójtowicz, P. Smoleń, Podatek dochodowy od osób fizycznych - prorodzinny czy neutralny, Warszawa 1999, passim; W. Wójtowicz, Teoretyczne modele opodatkowania dochodów osób fizycznych, [w:] P. Smoleń, W. Wójtowicz (red.), Prawo podatkowe, Warszawa 2017, s. 354 i nast.

${ }^{37}$ Wyrok TK z dnia 12 kwietnia 2011 r., SK 62/08, Lex/el; L. Etel (red.), Prawo podatkowe. Zarys wykładu, Warszawa 2013, s. 291.

${ }^{38}$ Wyrok WSA w Warszawie z dnia 29 stycznia 2013 r., III SA/Wa 2932/12, CBOSA; Z. Kukulski, D. Strzelec, Prawo..., s. 133-135; A. Olesińska, Polskie prawo podatkowe. Zarys systemu, Toruń 2012, s. 304.

${ }^{39}$ W. Wójtowicz, Problem „prorodzinności” podatku dochodowego od osób fizycznych, [w:] T. Dębowska-Romanowska, A. Jankiewicz (red.), Konstytucja, ustrój, system finansowy państwa. Księga pamiątkowa ku czci Profesor Natalii Gajl, Warszawa 1999, s. 407 i nast.; P. Pomorski, Podatek dochodowy od osób fizycznych, [w:] P. Smoleń, W. Wójtowicz (red.), Prawo..., s. 365.

${ }^{40}$ Wyrok TK z dnia 12 kwietnia 2011 r., SK 62/08, Lex/el; R. Mastalski, Prawo podatkowe, Warszawa 2012, s. 387 i nast. 
Zatem korzystający z łącznego rozliczenia podatku małżonkowie unikną, bądź też „spłaszczą” skutki progresji i związanej z nią zapłaty wyższego podatku od tej części dochodów, która przekracza podstawowy próg podatkowy przewidziany w art. 27 u.p.d.o.f. Innymi słowy, dwukrotność podatku wymierzanego od połowy sumy dochodów małżonków - na skutek zastosowania niższej stawki podatkowej - będzie mniejsza od sumy podatków obliczonych indywidualnie od dochodu każdego z małżonków ${ }^{41}$.

W wypadku łącznego opodatkowania małżonków ${ }^{42}$, ustawodawca zastosował, tzw. metodę ilorazu małżeńskiego, która polega na tym, że dodaje się dochody małżonków (po uprzednim odliczeniu - odrębnie dla każdego z małżonków - kwot podlegających odliczeniu ${ }^{43}$ ), ustala się kwotę stanowiącą połowę sumy dochodów małżonków, a od tak uzyskanej kwoty (będącej połową łącznych dochodów) oblicza się podatek, który następnie mnoży się przez dwa ${ }^{44}$. Biorąc pod uwagę trudną sytuację ekonomiczną wielu małżeństw, czy też niską, kwotę wolną od podatku, metodę ilorazu małżeńskiego należy ocenić pozytywnie, jako przykład rozwiązań prorodzinnych ${ }^{45}$.

Osoby, które pozostają w związkach partnerskich (w tym np. w konkubinacie) nie mogą korzystać z możliwości łącznego opodatkowania dochodów $^{46}$, ponieważ po pierwsze nie są małżonkami, a po drugie nie istnieje między nimi wspólność majątkowa ${ }^{47}$, jak tego wymaga art. 6 ust. 2 u.p.d.o.f. ${ }^{48}$. Innymi słowy, przepis art. 6 ust. 2 u.p.d.o.f. nie daje możliwości łącznego opodatkowania się osób heteroseksualnych pozostających we wspólnym pożyciu ${ }^{49}$. Także pozostawanie w jednopłciowym związku

\footnotetext{
${ }^{41}$ Wyrok TK z dnia 4 maja 2004 r., K 8/03, Lex/el.

${ }^{42}$ Art. 6 ust. 2 i 3 u.p.d.o.f.

${ }^{43}$ Określonych w art. 26 i art. 26a u.p.d.o.f.

${ }^{44}$ M. Majewicz, Opodatkowanie dochodów rodziny $w$ Polsce $w$ latach 1992-1994, Warszawa 1994, s. 12; wyrok TK z dnia 12 kwietnia 2011 r., SK 62/08, Lex/el.

45 I. Nowak, Wspólne..., s. 222; K. Święch, Pozycja rodziny w polskim prawie podatkowym 2013, Lex/el; M. Goettel, Niektóre..., s. 29.

${ }^{46} \mathrm{~J}$. Małecki, Prorodzinność podatku dochodowego od osób fizycznych, [w:] A. Gomułowicz, J. Małecki, Podatki i prawo podatkowe 2006, Lex/el.

${ }^{47}$ Por. I. Nowak, Opodatkowanie alimentów, [w:] J.M. Łukasiewicz, I. Ramus (red.), Prawo alimentacyjne. Zagadnienia systemowe i proceduralne, tom I, Toruń 2015, s. 199 i nast.

${ }^{48}$ Wyrok NSA z dnia 16 maja 1997 r., III SA 63/96, CBOSA.

${ }^{49}$ K. Koperkiewicz-Mordel, Podatek dochodowy od osób fizycznych, [w:] M. Sęk (red.), Prawo podatkowe. Podręcznik dla Podyplomowego Studium Prawa Podatkowego, t. 2, Łódź 2014, s. 338; wyroki NSA z dnia 20 marca 2012 r., II FSK 2082-2083/10, CBOSA.
} 
partnerskim nie daje podstawy do skorzystania $\mathrm{z}$ ulgi podatkowej z art. 6 u.p.d.o.f., albowiem ta preferencja podatkowa przysługuje wyłącznie małżonkom, którymi zgodnie z obowiązującymi przepisami Konstytucji RP i Kodeksu rodzinnego i opiekuńczego są mężczyzna i kobieta, którzy taki związek formalnie zawarli ${ }^{50}$. Także w piśmiennictwie prawa podatkowego powyższy pogląd judykatury znajduje pełną aprobatę, zgodnie, z którym „pozostawanie dwóch osób w faktycznym pożyciu (konkubinat, wolny związek partnerski) wyłącza możliwość wspólnego rozliczenia się na zasadach zastrzeżonych dla osób pozostających w związku małżeńskim" ${ }^{51}$. Zatem za prawidłowe należy uznać działania organów podatkowych, jeżeli odmówią zastosowania art. 6 ust. 2 u.p.d.o.f., względem związków partnerskich, powołując się przy tym na treści art. 18 Konstytucji RP ${ }^{52}$. Należy przy tym pamiętać, że jednym z podstawowych warunków preferencji podatkowej wspólnego opodatkowania małżonków jest pozostawanie przez nich w związku małżeńskim w rozumieniu prawa polskiego, co oznacza, iż

„nawet jeśli związek dwóch osób ma status równy lub zbliżony do statusu małżeństwa w myśl prawa obcego państwa (np. rejestrowany związek partnerski osób dowolnej płci we Francji lub małżeństwo homoseksualne), regulujące tę problematykę normy kolizyjne zawarte w międzynarodowym prawie prywatnym nie znajdą w takim wypadku zastosowania i nie będzie można domagać się rozciągnięcia przywilejów wynikających z komentowanego artykułu także na tego rodzaju związek"53.

Biorąc pod uwagę konstytucyjną zasadę ochrony małżeństwa oraz brak podstaw do uznania regulacji prawnej związków pozamałżeńskich za lukę $\mathrm{w}$ prawie, preferencje podatkowe w postaci wspólnego opodatkowania małżonków należy ze wszech miar uznać za trafne ${ }^{54}$. Również według Trybunału Konstytucyjnego w świetle aksjologii przyjętej w obowiązującej w Polsce Konstytucji, rodzina i małżeństwo są wartościami, które zajmują szczególnie wysoką rangę w hierarchii wartości konstytucyjnych ${ }^{55}$. Zatem przyznanie małżonkom prawa do łącznego rozliczenia podatku dochodowego od osób fizycznych stanowi konsekwencję tego, że małżeństwo, oprócz więzi duchowej i fizycznej, spaja również więź ekonomiczna,

${ }^{50}$ Wyrok WSA w Gdańsku z dnia 27 kwietnia 2010 r., I SA/Gd 99/10, CBOSA.

${ }^{51}$ Z. Kukulski, Komentarz do art. 6 u.p.d.o.f., [w:] W. Nykiel, A. Mariański (red.), Komentarz do ustawy o podatku dochodowym od osób fizycznych 2015, Gdańsk 2015, s. 116.

${ }^{52}$ Wyrok WSA w Gdańsku z dnia 11 maja 2010 r., I SA/Gd 205/10, CBOSA.

${ }^{53}$ Z. Kukulski, Komentarz..., s. 117-118.

${ }^{54}$ Wyrok SN z dnia 6 grudnia 2007 r., IV CSK 301/07, Lex/el.

${ }^{55}$ Wyrok TK z dnia 18 maja 2005 r., K 16/04, Lex/el. 
wyrażająca się w prowadzeniu wspólnego gospodarstwa domowego, a dochody uzyskiwane przez małżonków wydatkowane są na ich wspólne potrzeby, w tym wychowanie dzieci' ${ }^{56}$. Innymi słowy, wyłącznie związek kobiety i mężczyzny (małżeństwo) może być prawnie uznany przez państwo i korzystać z ochrony i opieki Rzeczypospolitej ${ }^{57}$, w tym z preferencji podatkowoprawnych na gruncie podatku dochodowego od osób fizycznych ${ }^{58}$.

4. Status maŁżonków W ŚWIETLE ART. 4A USTAWY O PODATKU OD SPADKÓW I DAROWIZN

W ustawie o podatku od spadków i darowizn z dniem 1 stycznia 2007 r. zaczął obowiązywać art. 4a, w którym ustawodawca unormował zwolnienie podatkowe dla osób najbliższych, m.in. dla małżonka ${ }^{59}$. Zgodnie art. 4a ust. 1 u.p.s.d. zwalnia się od podatku nabycie własności rzeczy lub praw majątkowych przez tzw. grupę zerową, tj. małżonka ${ }^{60}$, zstępnych, wstępnych, pasierba, rodzeństwo, ojczyma i macochę. Na marginesie należy tylko zauważyć, że w grupie zerowej nie znaleźli się zięć, synowa oraz teściowie, zaliczeni jako nabywcy do pierwszej grupy podatkowej ${ }^{61}$. Tym samym, grupa zerowa tylko częściowo pokrywa się z pierwszą grupą podatkową - nie zaliczono bowiem do niej zięcia, synowej i teściów.

Jak podnoszono $\mathrm{w}$ uzasadnieniu projektu ustawy o zmianie ustawy o podatku od spadków i darowizn oraz ustawy o podatku od czynności cywilnoprawnych „proponowana reforma podatku od spadków i darowizn

${ }^{56}$ Wyrok TK z dnia 12 kwietnia 2011 r., SK 62/08, Lex/el.

${ }^{57}$ W. Skrzydło, Konstytucja..., Lex/el.

${ }^{58}$ A. Gomułowicz, J. Małecki, Ustawa o podatku dochodowym od osób fizycznych. Komentarz 2003, Lex/el; I. Nowak, Przychody ze stosunku pracy a wspólne opodatkowanie małżonków, [w:] R. Frey (red.), Świadczenie pracy jako przedmiot zobowiązania umownego, Kielce 2013, s. 189-212.

${ }^{59}$ I. Nowak, Podatek od spadków i darowizn, [w:] M. Sęk (red.), Prawo podatkowe. Podręcznik dla Podyplomowego Studium Prawa Podatkowego, t. 3, Łódź 2014, s. 237 i nast.

60 Również małżonkowie pozostający w separacji korzystają ze zwolnienia z art. 4a u.p.s.d. - zob. wyrok NSA z dnia 23 kwietnia 2008 r., II FSK 373/07, CBOSA; E. Matyszewska, Darowizny między matżonkami: po separacji tė̇ jest ulga podatkowa, http://podatki.gazetaprawna.pl/artykuly/346338,darowizny_miedzy_malzonkami_po_ separacji_tez_jest_ulga_podatkowa.html.

${ }^{61}$ Według art. 14 ust. 3 pkt 1 u.p.s.d. do pierwszej grupy podatkowej zalicza się małżonka, zstępnych, wstępnych, pasierba, zięcia, synową, rodzeństwo, ojczyma, macochę i teściów. 
ma zapewnić możliwość przekazywania - nieuszczuplonego o kwotę podatku na rzecz państwa - majątku, będącego niejednokrotnie dorobkiem całego życia, między członkami najbliższej rodziny, co niewątpliwie przyczyni się do poprawy sytuacji majątkowej wielu rodzin" ${ }^{62}$. Analogicznie również czytamy w piśmiennictwie, że „celem zwolnienia podmiotowego w art. 4a. u.p.s.d. było zapewnienie ochrony interesów majątkowych członków najbliższej rodziny ze względu na szczególne powiązania osobiste i rodzinne między krewnymi w linii prostej i małżonkami, jak również przez wzgląd na uporządkowanie stosunków własnościowych dotyczących nieruchomości”63. Ponadto „przepis art. 4a ustawy o podatku od spadku i darowizn będący podstawą zwolnienia podatkowego przysługującego najbliższym członkom rodziny, zwalnia $\mathrm{z}$ opodatkowania dokonane $\mathrm{w}$ obrębie najbliższej rodziny przesunięcia praw majątkowych, pod warunkiem iż dokonane zostaną one w sposób jawny. Zabezpiecza to interesy skarbu państwa przed ewentualnymi nadużyciami ze strony podatników, którzy w celu uniknięcia odpowiedzialności podatkowej, mogliby powoływać się na fikcyjne czynności prawne dokonane pomiędzy najbliższymi członkami rodziny, czego zweryfikowanie w postępowaniu podatkowym stwarzałoby trudności”"64.

Przedstawione spostrzeżenia odpowiadają poglądom doktryny prawa podatkowego, w której podkreśla się, że „zasadniczym powodem wprowadzenia omawianego zwolnienia podmiotowego było zapewnienie szczególnej ochrony majątku najbliższej rodziny, a także stworzenie zachęty dla terminowego regulowania spraw własnościowych [...]"65. Innymi słowy, zwolnienie podmiotowe $\mathrm{z}$ art. $4 \mathrm{a}$ u.p.s.d. ma prorodzinny charakter ${ }^{66}$ poprzez redukcję, czy też wyłączenie ${ }^{67}$ osób najbliższych z zakresu ciężaru opodatkowania tym podatkiem i jest związane $z$ ukształtowaniem przez ustawodawcę podatku od spadków i darowizna, jako modelu podatku

${ }^{62}$ http://ww2.senat.pl/k6/dok/sejm/021/512.pdf.

${ }^{63}$ S. Babiarz, Spadek i darowizna w prawie cywilnym i podatkowym, Warszawa 2012, s. 390.

${ }^{64}$ Wyrok WSA w Rzeszowie z dnia 25 lipca 2011 r., I SA/Rz 234/2011, Lex/el.

${ }^{65}$ S. Babiarz, A. Mariański, W. Nykiel, Ustawa o podatku od spadków i darowizn. Komentarz, Warszawa 2010, s. 194; P. Borszowski, Komentarz do art. 4 a u.p.s.d., [w:] P. Borszowski, J. Wantoch-Rekowski, A. Nita, K. Stelmaszczyk, K. Musiał, Ustawa o podatku od spadków i darowizn. Komentarz 2017, Lex/el.

${ }^{66}$ K. Koperkiewicz-Mordel, Podatek od spadków i darowizn, [w:] W. Nykiel (red.), Prawo podatkowe w Polsce. Podręcznik akademicki, Warszawa 2018, s. 368.

${ }^{67}$ W. Nykiel, Ulgi i zwolnienia w konstrukcji prawnej podatku, Warszawa 2002, passim. 
osobistego z podziałem podatników na grupy podatkowe według kryterium więzów rodzinnych ${ }^{68}$.

Jedynie małżeństwo zawarte zgodnie z prawem uzasadnia traktowanie podmiotu jako małżonka w rozumieniu art. 4a u.p.s.d. ${ }^{69}$. Wywieść $\mathrm{z}$ tego należy, że osoby tej samej płci pozostające w stałym związku partnerskim nie mogą skorzystać ze zwolnienia między członkami najbliższej rodziny ${ }^{70}$. Także pozostawanie $\mathrm{w}$ jednopłciowym związku partnerskim nie stanowi samodzielnej podstawy do skorzystania ze zwolnienia podatkowego wynikającej $\mathrm{z}$ art. 4a u.p.s.d., albowiem zwolnienie to przysługuje jedynie małżonkom, którymi zgodnie z obowiązującymi przepisami Konstytucji RP i ustawy Kodeks rodzinny i opiekuńczy są mężczyzna i kobieta, którzy taki związek formalnie zawarli ${ }^{71}$. Pogląd ten potwierdza również judykatura, zauważając, że „jeśli nawet uznać, że w przepisach prawa podatkowego występuje luka nie uwzględniająca wśród beneficjentów zwolnienia, o którym stanowi art. 4a ustawy podatkowej, osób tej samej płci pozostających w związkach partnerskich, to normy obejmującej te osoby zwolnieniami podatkowym nie można odtwarzać $\mathrm{w}$ drodze wnioskowania $\mathrm{z}$ analogi. Regulacja zawarta w art. 4a ustawy nie ma bowiem charakteru otwartego lub niezupełnego. Wręcz przeciwnie, dyrektywy językowe i systemowe jednoznacznie wskazują, że przepis art. 4a dotyczy wyłącznie stanu faktycznego w nim wyznaczonego, tak pod względem przedmiotowym, jak podmiotowym. Objęcie więc w drodze wnioskowania $\mathrm{z}$ analogii związków partnerskich osób tej samej płci pojęciem rodziny, oraz traktowanie ich jak małżonków, jest sprzeczne z konstytucją i stanowi próbę obejścia przepisów prawa podatkowego ujętych w art. 4a ustawy o podatku od spadków i darowizn"72. Co więcej, art. 4a u.p.s.d. nie można interpretować w oderwaniu od treść art. 18 Konstytucji RP, albowiem stanowi on expressis verbis, że małżeństwo jako związek kobiety i mężczyzny

${ }^{68}$ Zob. P. Smoleń, Kształtowanie obciążenia w podatku od spadków i darowizn, Lublin 2006, passim; A. Błaszczyk, Podatek od spadków i darowizn - zwolnienie nabycia rzeczy i praw majątkowych przez osoby najbliższe, [w:] J. Glumińska-Pawlic (red.), Doradca podatkowy obrońca praw podatnika, Katowice 2008, s. 20; K. Chustecka, Podatek od spadków i darowizn. Praktyka i orzecznictwo, Warszawa 2010, s. 95.

${ }^{69}$ W. Stachurski, Komentarz do art. 4a. u.p.s.d., [w:] S. Bogucki, A. Cudak, P. Pietrasz, W. Stachurski, K. Winiarski, A. Wrzesińska-Nowacka, Podatek od spadków i darowizn. Komentarz, Gdańsk 2015, s. 199; wyrok WSA w Gdańsku z dnia 2 czerwca 2015 r., I SA/Gd $468 / 15$, CBOSA.

${ }^{70}$ Wyrok NSA z dnia 20 marca 2012 r., II FSK 1704/10, CBOSA.

${ }^{71}$ Por. wyrok WSA w Gdańsku z dnia 27 kwietnia 2010 r., I SA/Gd 99/10, CBOSA.

${ }^{72}$ Wyrok NSA z dnia 20 marca 2012 r., II FSK 1704/10, CBOSA. 
znajdują się pod ochroną i opieką Rzeczypospolitej Polskiej ${ }^{73}$, przez co do grupy osób, którym przysługuje zwolnienie z art. 4a u.p.s.d., nie zalicza się osób pozostających w związkach partnerskich ${ }^{74}$.

Konkludując, należy podkreślić, że zwolnienie podmiotowe z art. 4a u.p.s.d. poprzez wyłączenie (redukcję) ${ }^{75}$ małżonków z ciężaru opodatkowania jest „ukłonem” normodawcy w kierunku prorodzinnego charakte$\mathrm{ru}^{76}$ podatku od spadków i darowizn, jako modelu podatku osobistego ${ }^{77}$. Wszystko to prowadzi do wniosku, że na gruncie podatku od spadków i darowizn „mamy do czynienia ze zdarzeniami cywilnoprawnymi, które w większości przypadków zachodzą w obrębie stosunków wewnątrzrodzinnych. Mając na uwadze ideę prorodzinności systemu podatkowego, ustawodawca uzależnił wysokość podatku nie tylko od wartości przysporzenia, lecz także od stopnia pokrewieństwa i powinowactwa między beneficjentem tego przysporzenia a darczyńcą lub spadkodawcą"78. Warto $\mathrm{w}$ tym miejscu podkreślić, że również w świetle art. 9 pkt 10 lit. b) ustawy o podatku od czynności cywilnoprawnych ${ }^{79}$ zwalnia się od tejże daniny publicznoprawnej pożyczki w wysokości przekraczającej kwotę 9637 zł., udzielane w formie pieniężnej na podstawie umowy zawartej między osobami, o których mowa w art. 4 a u.p.s.d. ${ }^{80}$, w tym też

${ }^{73}$ Wyrok NSA z dnia 28 października 2016 r., II FSK 2835/14, CBOSA.

${ }^{74} \mathrm{~J}$. Banach, Zwolnienie z podatku od spadków i darowizn nabycia własności rzeczy lub praw majątkowych przez osoby najbliższe, „Biuletyn Skarbowy” 2009, nr 6, s. 9; K. Górczak, Konkubent zapłaci podatek i od darowizn, i od spadku, http://podatki.gazetaprawna.pl/artykuly/401357,konkubent_zaplaci_podatek_i_od_darowizn_i_od_spadku.html; A. Tarka, Konkubenci na oku fiskusa, http://www.rp.pl/artykul/793727,890055-Podatek-od-darowizny-w-konkubinacie.html; wyrok WSA w Poznaniu z dnia 25 lutego 2014 r., III SA/Po 722/13, CBOSA.

${ }^{75}$ W. Nykiel, Ulgi...

${ }^{76}$ K. Koperkiewicz-Mordel, Podatek..., s. 368.

${ }^{77}$ Zob. P. Smoleń, Kształtowanie..., passim; A. Błaszczyk, Podatek..., s. 20; K. Chustecka, Podatek..., s. 95.

${ }^{78}$ M. Goettel (red.), M. Lemonnier (red.), A. Goettel, J. Orłowski, B. Pahl, M. Tyrakowski, K. Wardencka, J.J. Zięty, Instytucje prawa cywilnego w konstrukcji prawnej podatków 2011, Lex/el; szerzej S. Babiarz, Spadek..., s. 390.

${ }^{79}$ Ustawa z dnia 9 września 2000 r. o podatku od czynności cywilnoprawnych, tekst jednolity: Dz.U. z 2017 r., poz. 1150 ze zm.; dalej: u.p.c.c.

${ }^{80}$ Szerzej Z. Ofiarski, Ustawa o opłacie skarbowej. Ustawa o podatku od czynności cywilnoprawnych. Komentarz 2018, Lex/el; H. Filipczyk, Podatek od czynności cywilno-prawnych. Komentarz 2015, Lex/el. 
małżonka ${ }^{81}$. „Tym sposobem uzyskana od małżonka pożyczka, korzystając $z$ instytucji zwolnienia podatkowego nie powoduje obowiązku zapłaty podatku, przyczyniając się do podkreślenia jaki wpływ na kształtowanie się zobowiązań podatkowych ma trwałość węzła małżeńskiego" ${ }^{82}$.

\section{MAŁŻONEK STRONY JAKO PEŁNOMOCNIK (DOMNIEMANY PEŁNOMOCNIK) W ŚWIETLE ORDYNACJI PODATKOWEJ}

W świetle art. 138b $\$ 3$ o.p. w kwestiach mniejszej wagi wynikających w toku postępowania, organ podatkowy może nie żądać pełnomocnictwa, jeżeli pełnomocnikiem jest małżonek strony, a nie ma wątpliwości co do istnienia i zakresu jego upoważnienia do występowania w imieniu strony. Jest to jedyny wyjątek od wymogu złożenia pełnomocnictwa w procedurze podatkowej, oparty na tzw. nieformalnym pełnomocnictwie ${ }^{83}$, czy też domniemanym pełnomocnictwie ${ }^{84}$, czyli sytuacji, która „sprowadza się do zaniechania przez organ podatkowy żądania pełnomocnictwa od osoby działającej w imieniu strony w ściśle określonych w ustawie przypadkach" ${ }^{\prime 5}$. Innymi słowy, organ podatkowy może nie żądać (zaniechać żądania) pełnomocnictwa wyłącznie w sytuacji, gdy pełnomocnikiem jest małżonek strony, a nie ma wątpliwości co do istnienia i zakresu jego upoważnienia ${ }^{86}$.

${ }^{81}$ S. Bogucki, Komentarz do art. 9 pkt 10 lit. b) u.p.c.c., [w:] S. Bogucki, A. Dumas, W. Stachurski, K. Winiarski, Podatek od czynności cywilnoprawnych. Komentarz dla praktyków, Gdańsk 2014, s. 303-307; A. Goettel, Kontrowersje wokół przesłanek zwolnienia od podatku pożyczek udzielanych osobom bliskim (na kanwie wyroku sądu administracyjnego), „Monitor Podatkowy” 2011, nr 6; wyrok WSA w Łodzi z dnia 22 stycznia 2016 r., I SA/Łd 1150/15, CBOSA.

${ }^{82}$ M. Klink, Instytucja małżeństwa w polskim prawie podatkowym, [w:] I. Czaja-Hliniak (red.), Nauka prawa finansowego po I dekadzie XXI wieku. Ksiega pamiątkowa dedykowana Profesorowi Apoloniuszowi Kosteckiemu, Kraków 2012, s. 471.

${ }^{83}$ J. Borkowski, B. Adamiak, Komentarz do art. $138 b$ o.p., [w:] B. Adamiak, J. Borkowski, P. Borszowski, R. Mastalski, J. Zubrzycki, Ordynacja podatkowa. Komentarz 2017, Wrocław 2017, s. 864.

${ }^{84} \mathrm{P}$. Karwat, Jak uniknać nieporozumień zorganami podatkowymi przy ustanawianiu i odwoływaniu pełnomocnictwa?, „Prawo i Podatki” 2006, nr 4, s. 21.

${ }^{85}$ W. Stachurski, Komentarz do art. 138 b.p., [w:] L. Etel (red.), Ordynacja podatkowa. Komentarz aktualizowany 2018, Lex/el.

${ }^{86}$ I. Nowak, B. Rutkowski, Petnomocnictwo $w$ świetle ordynacji podatkowej - stan obecny a planowane zmiany, „Toruński Rocznik Podatkowy” 2014/el; I. Nowak, Skutki pominięcia pełnomocnika w sprawie podatkowej, [w:] R. Frey (red.), Przemiany prawa publicznego i prywatnego na początku XXI wieku, Kielce 2012, s. 200-201; idem, Udzielenie 
„Istota domniemanego pełnomocnictwa sprowadza się do zaniechania przez organ podatkowy żądania pełnomocnictwa od osoby działającej w imieniu strony w ściśle określonych w ustawie przypadkach"87, jeżeli zostaną spełnione łącznie cztery przesłanki:

a) czynność dotyczy poszczególnych kwestii procesowych a nie całej sprawy podatkowej ${ }^{88}$,

b) kwestie procesowe są mniejszej wagi ${ }^{89}$, przez co nie zmieniają istoty sprawy,

c) czynności dokonuje małżonek podatnika,

d) nie ma żadnych wątpliwości co do istnienia i zakresu upoważnienia małżonka do występowania w imieniu strony ${ }^{90}$.

Dopuszczenie w postępowaniu podatkowym domniemanego pełnomocnika (małżonka) należy traktować, jak się wydaje, jako wyraz ograniczonego formalizmu, który „może sprzyjać usunięciu wielu występujących w praktyce uciążliwości związanych z postępowaniem podatkowym dotyczącym małżonków i zwiększać skuteczność procesu podatkowego" ${ }^{91}$. Nie należy jednak zapominać, że jest to instytucja wyjątkowa, przy której organ podatkowy będzie zawsze zobowiązany zachować szczególną ostrożność, m.in. w ocenie samej sprawy podatkowej - czy jest ona "mniejszej wagi”, czy też ustalenia, że „nie ma wątpliwości” odnośnie do reprezentowania strony i jego zakresu' ${ }^{92}$.

petnomocnictwa a jego cofnięcie w postępowaniu podatkowym - wybrane aspekty, „Przegląd Podatków Lokalnych i Finansów Samorządowych" 2013, nr 2, s. 26; A. Biegalski, Petnomocnik strony w postępowaniu podatkowym, „Prawo i Podatki” 2009, nr 8, s. 29.

${ }^{87}$ W. Stachurski, Komentarz do art. 138 b.p., [w:] L. Etel (red.), Ordynacja podatkowa. Komentarz 2017, Lex/el.

${ }^{88}$ Por. A. Matan, Zastępstwo procesowe w ogólnym postępowaniu administracyjnym, Katowice 2001, s. 184.

${ }^{89}$ Por. P. Gołaszewski, Komentarz do art. 33 k.p.a., [w:] R. Hauser, M. Wierzbowski (red.), Kodeks postępowania administracyjnego. Komentarz 2018, Legalis/el; K. Startek, Petnomocnictwo w prawie podatkowym, „Przegląd Podatkowy” 2008, nr 5, s. 30.

${ }^{90}$ J. Borkowski, B. Adamiak, Komentarz do art. $138 b$ o.p., [w:] B. Adamiak, J. Borkowski, P. Borszowski, R. Mastalski, J. Zubrzycki, Ordynacja..., s. 864; A. Kabat, Komentarz do art. 138 b.p., [w:] S. Babiarz, B. Dauter, B. Gruszczyński, R. Hauser, A. Kabat, M. Niezgódka-Medek, J. Rudowski, Ordynacja podatkowa. Komentarz, Warszawa 2017, Lex/el.

${ }^{91}$ K. Ignaczak, Komentarz do art. $138 b$ o.p., [w:] H. Dzwonkowski (red.), Ordynacja podatkowa. Komentarz 2018, Legalis/el.

${ }^{92}$ Por.J. Borkowski, B. Adamiak, Komentarz do art. 33 k.p.a., [w:] B. Adamiak, J. Borkowski, Kodeks postępowania administracyjnego. Komentarz 2017, Legalis/el; por. wyrok NSA z dnia 8 kwietnia 2011 r., I OSK 858/10, Legalis nr 367377; wyrok WSA w Lublinie z dnia 28 stycznia 
Podsumowując powyższe rozważania należy dostrzec, że w art. 138b $\$ 3$ o.p. mamy do czynienia $z$ unormowaniem, u „podstaw którego legł expressis verbis czynnik małżeński”, a „intencją ustawodawcy było częściowe odformalizowanie postępowania podatkowego w sytuacji, gdy jego stroną jest osoba pozostająca w stosunku małżeństwa, małżonek strony zaś pełni funkcję pełnomocnika"93. Oznacza to, że prawodawca traktując małżeństwo jako szczególnego rodzaju więź kobiety i mężczyzny (art. 18 Konstytucji $\mathrm{RP}$ ), dopuszcza odformalizowanie procedury podatkowej, m.in. wprowadzając wyjątek od wymogu złożenia pełnomocnictwa w procesie podatkowym. Tym samym, zawarcie małżeństwa rodzi skutki nie tylko w wymiarze społecznym, osobistym, ale także proceduralnopodatkowym ${ }^{94}$.

\section{OSOBY POZOSTAJĄCE Z PODATNIKIEM W FAKTYCZNYM POŻYCIU} W ŚWIETLE ART. $111 \$ 3$ O.P. JAKO CZŁONEK RODZINY PODATNIKA

W art. $111 \$ 3$ Ordynacji podatkowej, która co do zasady jest uważana za akt ogólnego prawa podatkowego, za członków rodziny podatnika ustawodawca uważa zstępnych, wstępnych, rodzeństwo, małżonków zstępnych, osobę pozostającą w stosunku przysposobienia oraz pozostającą z podatnikiem w faktycznym pożyciu' ${ }^{95}$. Bez wątpienia art. $111 \S 3$ o.p. in fine odnosi się do osób żyjących w związkach partnerskich (np. konkubinacie ${ }^{96}$. Powstaje więc pytanie, czy Ordynacja podatkowa zawiera uniwersalną definicję członka rodziny podatnika, którą można stosować

2014 r., III SA/Lu 301/13, CBOSA; R. Kędziora, Kodeks postępowania administracyjnego. Komentarz 2017, Legalis/el.

${ }^{93}$ A. Goettel, Podatkowoprawne skutki zawarcia i ustania małżeństwa 2016, Lex/el.

${ }^{94}$ I. Nowak, B. Rutkowski, Pełnomocnictwo..., „Toruński Rocznik Podatkowy” 2014/el; por. wyrok ETPC z dnia 24 czerwca 2010 r., Schalk i Kopf v. Austria 30141/04, Lex/el; M. Münnich, Małżonkowie jako strona procedur podatkowych uregulowanych w Ordynacji podatkowej, [w:] M. Popławski (red.), Ordynacja podatkowa. Zagadnienia proceduralne, Białystok 2011, s. 19 i nast.

${ }^{95}$ Por. B. Brzeziński, J. Jaworski, Konkubinat..., s. 92.

96 Jednakże „w tym przypadku pociągnięcie do odpowiedzialności konkubiny czy konkubenta jest często trudne, zważywszy na fakt, że mamy do czynienia ze stanem faktycznym, a nie prawnym, którego istnienie organ podatkowy musi udowodnić" - R. Dowgier, Komentarz do art. 111 o.p., [w:] L. Etel (red.), Ordynacja podatkowa. Komentarz aktualizowany 2018, Lex/el; podobnie A. Mariański, Odpowiedzialność osób trzecich za zobowiązania podatkowe. Podstawy i wyłaczenia, Gdańsk 2004, s. 13; S. Babiarz, Komentarz do art. 111 o.p., [w:] B. Dauter, R. Hauser, A. Kabat, M. Niezgódka-Medek, J. Rudowski, Ordynacja..., Lex/el. 
na gruncie ustaw podatkowych szczególnych? Ten problem dostrzeżony został również w orzecznictwie, w którym co do zasady trafnie wskazano, że art. 111 o.p. zawarty jest w Dziale III Rozdziale 15 Ordynacji podatkowej, pt. „Odpowiedzialność podatkowa osób trzecich”97, przez co przepisy tego rozdziału dotyczą jedynie odpowiedzialności za zaległości podatkowe podatnika osób innych niż podatnik, ponieważ chodzi w tym przypadku o sytuację wyjątkową, jaką jest odpowiedzialność innej osoby niż podatnik i ustawodawca dla potrzeb tego unormowania zadecydował o zawężeniu pojęcia „członka rodziny” wyłącznie do „zstępnych, wstępnych, rodzeństwa, małżonków zstępnych, osoby pozostającej w stosunku przysposobienia oraz pozostającej z podatnikiem w faktycznym pożyciu"98. Warto przy tym zwrócić uwagę, że w art. $111 \S 3$ o.p. ustawodawca użył określenia za członka rodziny „uważa się”, co dodatkowo potwierdza tezę, iż regulacji tej nie można odnosić do innych stanów prawnych i faktycznych ${ }^{99}$. Z tych też względów, użyte $w$ art. $111 \$ 3$ o.p. pojęcie członek rodziny, nie może mieć zastosowania przy definiowaniu tego określenia zamieszczonego w ustawach materialnego prawa podatkowego ${ }^{100}$. Także $\mathrm{w}$ doktrynie takie podejście znajduje aprobatę, ponieważ „znaczenie i zasięg definicji zawartej $\mathrm{w}$ art. $111 \S 3$ o.p. nie może być oceniane w oderwaniu od uwarunkowań systemowych. Odnosi się to do położenia przepisu w strukturze aktu normatywnego oraz funkcji, jaką spełnia w ramach instytucji prawnej, której dotyczy"101. Nasuwa się wobec tego spostrzeżenie, że należy opowiedzieć się za zastosowaniem definicji tylko i wyłącznie do ustalenia kręgu podmiotów odpowiedzialnych za zobowiązania podatkowe (odpowiedzialności osób trzecich za zaległości podatkowe) ${ }^{102}$, ponieważ „gdyby definicja miała znaleźć szersze zastosowanie, powinna być ulokowana - z oczywistych względów systematyzacyjnych - w Dziale I Ordynacji podatkowej „przepisy ogólne” ${ }^{103}$. Podsumowując powyższe rozważania należy dostrzec,

${ }^{97}$ B. Brzeziński, A. Olesińska, Zagadnienia odpowiedzialności w prawie podatkowym, [w:] B. Brzeziński, A. Olesińska, J. Pustuł (red.), Odpowiedzialność i sankcje w prawie podatkowym, Toruń 2017, s. 15; A. Olesińska, Odpowiedzialność osób trzecich za zobowiązania podatkowe, Lubin 2000.

${ }_{98}$ Wyrok WSA w Gliwicach z dnia 8 czerwca 2010 r., I SA/Gl 272/10, CBOSA.

${ }^{99}$ Wyrok NSA z dnia 25 maja 2012 r., II FSK 2116/10, CBOSA.

${ }^{100}$ Wyrok WSA w Gliwicach z dnia 8 czerwca 2010 r., I SA/Gl 272/10, CBOSA.

101 B. Brzeziński, Glosa do wyroku NSA z dnia 21 lutego 2001 r., I SA/Gd 1012/99, „Przegląd Orzecznictwa Podatkowego” 2002, nr 3, s. 370.

${ }^{102}$ B. Brzeziński, J. Jezierski, Konkubinat..., s. 96-97.

${ }^{103}$ B. Brzeziński, Glosa..., s. 370. 
że art. $111 \$ 3$ o.p. nie zawiera uniwersalnej definicji członka rodziny, mającej zastosowanie do innych sytuacji objętych regulacjami podatkowoprawnymi, przeciwnie - ma charakter autonomiczny ${ }^{104}$.

\section{OSOBY POZOSTAJĄCE FAKTYCZNIE WE WSPÓLNYM POŻYCIU MAŁŻEŃSKIM W ŚWIETLE ART. 4 UST. 1 PKT 6 USTAWY O PODATKU OD SPADKÓW I DAROWIZN}

Zgodnie z art. 4 ust. 1 pkt 6 u.p.s.d. zwalnia się od podatku nabycie w drodze darowizny praw do rachunku oszczędnościowo-kredytowego przez osobę pozostającą faktycznie we wspólnym pożyciu małżeńskim z posiadaczem rachunku oszczędnościowo-kredytowego w kasie mieszkaniowej, pod warunkiem przeznaczenia środków zgromadzonych na tym rachunku na cele mieszkaniowe. W związku ze stylizacją ww. przepisu rodzi się następujące pytania: co należy rozumieć pod zwrotem „osoby pozostającej faktycznie we wspólnym pożyciu małżeńskim”, ponieważ nie został on zdefiniowany i do jakiego kręgu podmiotów prawodawca kieruje to zwolnienie?

Po pierwsze, co zostało już dostatecznie mocno wyargumentowane powyżej, polskie prawo (także podatkowe), preferując rodzinę opartą na małżeństwie ${ }^{105}$, nie przewiduje możliwości sformalizowania związku w innej formie. Zatem sytuacja osób pozostających w związku partnerskim, np. konkubenckim ${ }^{106}$, tj. we wspólnym faktycznym pożyciu, nie jest tożsama $\mathrm{z}$ sytuacją prawną osób faktycznie pozostających we wspólnym pożyciu małżeńskim, przez co, nie można stawiać znaku równości między tymi zwrotami.

Po drugie, wspólne pożycie z art. 4 ust. 1 pkt 6 u.p.s.d. występuje z przydawką/ dystynkcją „małżeńskie”"107, przez co zwrot „osoba, która po-

${ }^{104}$ Wyrok NSA z dnia 25 maja 2012 r., II FSK 2116/10, CBOSA; B. Brzeziński, J. Jezierski, Konkubinat..., s. 100; B. Brzeziński, J. Jezierski, Pozycja rodziny w polskim prawie podatkowym, [w:] J. Głuchowski (red.), Studia podatkowe, Toruń 1991, s. 118; Z. Ofiarski, Ogólne prawo podatkowe. Zagadnienia materialnoprawne i proceduralne 2013, Lex/el; wyrok WSA w Gliwicach z dnia 8 czerwca 2010 r., I SA/Gl 272/10, CBOSA; wyrok NSA z dnia 20 marca 2012 r., II FSK 2082/10, CBOSA; odmiennie wyrok NSA z dnia 21 lutego 2001 r., I SA/Gd 1012/99, CBOSA.

${ }^{105}$ E. Słotwińska-Rosłanowska, Zmiana demograficznego modelu rodziny a ewolucja prawa rodzinnego $w$ kontekście kohabitacji w Europie, „Zeszyty Naukowe Uniwersytetu Ekonomicznego w Katowicach" 2017, nr 309.

${ }^{106}$ Wyrok SN z dnia 3 marca 2015 r., IV KO 1/15, Lex/el.

${ }^{107}$ W. Stachurski, Komentarz do art. 4 u.p.s.d., [w:] S. Bogucki, A. Cudak, P. Pietrasz, W. Stachurski, K. Winiarski, A. Wrzesińska-Nowacka, Podatek..., s. 177. 
zostaje faktycznie we wspólnym pożyciu małżeńskim” nie można żadną miarą przeciwstawiać pojęciu „małżeństwo”, ponieważ w tym ostatnim pojęciu mieszczą się wszak zarówno małżonkowie pozostający we wspólnym pożyciu, jak i małżonkowie, których pożycie uległo rozkładowi, ale których małżeństwo nie zostało rozwiązane ${ }^{108}$. Jednakże odnosząc to na grunt analizowanego zwolnienia „najistotniejszym elementem w zakresie stosowania tego zwolnienia jest ustalenie, czy osoby chcące $\mathrm{z}$ niego skorzystać, pozostają ze sobą w takiej relacji, iż z punktu widzenia otaczającego nas społeczeństwa mogą być uznane za rodzinę rozumianą jako związek małżeński w rozumieniu konstytucyjnym, nie zaś czy są małżeństwem z punktu widzenia formalnego" ${ }^{109}$.

Mając na uwadze powyższe rozważania, nie można podzielać poglądów zgłaszanych w piśmiennictwie, jakoby przez osoby pozostające faktycznie we wspólnym pożyciu małżeńskim można było rozumieć osoby tworzące związki partnerskie, np. konkubentów ${ }^{110}$, czy też „osoby odmiennej płci nie będące małżeństwem"111. Niestety, także sądy administracyjne legitymizują taki stan rzeczy, przyzwalając tym samym organom podatkowych na działania, które nie mają umocowania w przepisach rangi ustawowej ${ }^{112}$.

\section{WNIOSKI}

W świetle polskiego prawa, z Konstytucją RP na czele, niemożliwe jest zawarcie związku małżeńskiego przez związki partnerskie ${ }^{113}$. A contrario, objęcie $\mathrm{w}$ drodze wnioskowania $\mathrm{z}$ analogii związków partnerskich osób tej samej lub odmiennej płci pojęciem małżeństwa oraz traktowanie ich

${ }^{108}$ Por. R. Malarski, Zdanie odrębne do uchwaty SN z dnia 25 lutego 2016 r., I KZP 20/15, Lex/el.

${ }^{109}$ K. Musiał, Komentarz do art. 4 u.p.s.d., [w:] P. Borszowski, J. Wantoch-Rekowski, A. Nita, K. Stelmaszczyk, K. Musiał, Ustawa..., Lex/el.

${ }^{110}$ M. Rusinek, Podatek od spadków i darowizn. Komentarz do zmian wprowadzonych ustawa z dnia 16 listopada 2006 r. o zmianie ustawy o podatku od spadków i darowizn oraz ustawy o podatku od czynności cywilnoprawnych, Lex/el; M. Klink, Instytucja..., s. 469.

${ }^{111}$ W. Stachurski, Komentarz do art. 4a. u.p.s.d...., s. 177.

${ }^{112}$ Szerzej A. Mariański, O potrzebie zmiany praktyki stosowania prawa podatkowego. Glosa do wyroku TK z dnia 18 lipca 2013 r., (SK 18/09), „Monitor Podatkowy” 2013, nr 11, s. 46-50; wyrok NSA z dnia 28 października 2016 r., II FSK 2835/14, CBOSA; wyrok NSA z dnia 20 marca 2012 r., II FSK 2082-2083/10, CBOSA.

${ }^{113}$ M. Wojewoda, Małżeństwa jednopłciowe i związki partnerskie w polskim rejestrze stanu cywilnego?, „Studia Prawno-Ekonomiczne” 2017, t. CIII, s. 133 i nast. 
jak małżonków, byłoby sprzeczne z Konstytucją RP i stanowiło działanie contra legem ${ }^{114}$. Ponadto $\mathrm{w}$ polskim systemie prawnym - w tym także podatkowym - brak jest przepisów rangi ustawowej, które wprowadzałyby i uznawały (instytucjonalizowałyby) związki partnerskie par homoseksualnych, czy też heteroseksualnych za uznane prawnie ${ }^{115}$. Zwraca na to uwage również orzecznictwo sądowe, podnosząc, że także na gruncie przepisów podatkowych nie ma podstaw do tego, aby poszukiwać odmiennego rozumienia małżeństwa niż to, które zostało ukształtowane w prawie rodzinnym, ponieważ brak bowiem w tych przepisach - poza wskazaniem instytucji małżeństwa określonej przepisami prawa rodzinnego - odmiennych regulacji mających zastosowanie wyłącznie na gruncie prawa podatkowego $^{116}$. Także w doktrynie prawa podatkowego powyższy pogląd judykatury znajduje pełną aprobatę, zgodnie z którym „w żadnym jednak wypadku $\mathrm{w}$ obszarze polskiego porządku prawnego (tym samami ustawodawstwa podatkowego) nie ma podstaw do zrównania związków konkubenckich - czy to heteroseksualnych, czy to homoseksualnych - ze związkami małżeńskimi”"117. Inaczej rzecz ujmując, związki partnerskie są kategorią stanów faktycznych, a nie instytucją prawną, ponieważ ustawodawca preferuje małżeństwo jako podstawę stosunków rodzinnych ${ }^{118}$.

Brak instytucjonalizacji związków partnerskich jest wyrazem ustanowienia małżeństwa jako fundamentu rodziny i nie ulega wątpliwości, że także prawo podatkowe w tej kwestii nie pozostaje "obojętne” wobec związku małżeńskiego ${ }^{119}$. Co więcej, ochrona małżeństwa przejawia się m.in. w tym, że do innych związków nie stosuje się skutków prawnych wynikających z zawarcia małżeństwa oraz że nie dopuszcza się takiej wykładni i stosowania

${ }^{114}$ B. Banaszkiewicz, Problem konstytucyjnej oceny instytucjonalizacji związków homoseksualnych, „Kwartalnik Prawa Prywatnego” 2004, nr 2, s. 380 i nast.; idem „Małżeństwo jako związek kobiety i mężczyzny". O niektórych implikacjach art. 18 Konstytucji RP, „Kwartalnik Prawa Prywatnego” 2013, nr 3, s. 591 i nast.; wyrok NSA z dnia 20 marca 2012 r., II FSK 1704/10, CBOSA.

115 J. Boć (red.), Konstytucje Rzeczypospolitej oraz komentarz do Konstytucji RP z 1997 roku, Wrocław 1998, s. 48; P. Winczorek, Komentarz..., s. 54; wyrok NSA z dnia 20 marca 2012 r., II FSK 2082/10, CBOSA.

${ }^{116}$ Wyrok WSA w Gdańsku z dnia 27 kwietnia 2010 r., I SA/Gd 99/10, CBOSA; wyrok NSA z dnia 23 kwietnia 2008 r., II FSK 373/07, CBOSA.

${ }^{117}$ A. Goettel, Podatkowoprawne..., Lex/el.

${ }^{118}$ B. Brzeziński, J. Jezierski, Konkubinat..., s. 91.

${ }^{119}$ A. Olesińska, Wspólność majątkowa małżeńska a ogólne prawo podatkowe, [w:] Regulacje..., s. 221 i nast. 
przepisów, które prowadziłyby do zrównania pod względem prawnym małżeństwa i innych form pożycia ${ }^{120}$. Nie bez racji wskazuje się w doktrynie, że małżeństwo to instytucja o charakterze ponadczasowym, zastanym, nieprzemijająca, znajdująca się na mocy art. 18 Konstytucji RP pod ochroną państwa polskiego, zasługująca w całej rozciągłości na preferencje podatkowe ${ }^{121}$. Konsekwencją tego stanu rzeczy jest bez wątpienia fakt, że „prawo podatkowe oparło się niezwykle skutecznie nie formalizacji związków partnerskich, stojąc na straży trwałości węzła małżeńskiego" ${ }^{122}$, a nie np. związków poligamicznych, hybrydowych, na próbę, tymczasowych ${ }^{123}$.

Charakter prawny małżeństwa - stałego związku kobiety i mężczyzny $^{124}$ - wypływający z art. 18 Konstytucji RP identyfikuje małżeństwo, jako wyłączny związek heteroseksualny z możliwościami prokreacyjny$\mathrm{mi}^{125}$. W związku z tym nie można podzielić poglądu, że „art. 18 Konstytucji określający explicite małżeństwo jako związek kobiety i mężczyzny, nie wyklucza małżeństw o innej podmiotowej strukturze"126. Także według K. Święch, „zasada odmienności płci małżonków stanowi istotną dyrektywę dla projektodawcy ustawy normującej prawo małżeńskie, a zatem przyjmuje się, że w sprzeczności z Konstytucją RP pozostaje ewentualna legalizacja związków homoseksualnych"127. Innymi słowy, tylko związek kobiety i mężczyzny (małżeństwo) może być prawnie uznany przez państwo i korzystać z ochrony i opieki Rzeczypospolitej ${ }^{128}$, w tym z preferencji podatkowoprawnych. Analogicznie zauważa W. Skrzydło, że „wobec sporów i kontrowersji, jakie pojawiły się w toku prac nad Konstytucją, a także w obliczu żądań mniejszości seksualnych domagających się uznania ich praw do zakładania rodziny i zawierania związków małżeńskich, Konsty-

${ }^{120}$ Wyrok NSA z dnia 11 marca 2016 r., II FSK 1682/14, CBOSA.

${ }^{121}$ M. Klink, Instytucja..., s. 465 i nast.

${ }^{122}$ Ibidem, s. 477.

${ }^{123}$ Z. Strus, Znaczenie artykułu 18 Konstytucji Rzeczypospolitej Polskie, „Palestra” 2014, nr 9, s. 233 i nast.

${ }^{124}$ J. Halberda, Zniesienie separacji, „Rejent” 2004, nr 2, s. 39 i nast.

${ }^{125}$ M. Pilich, Związki quasi-małżeńskie $w$ polskim prawie prywatnym międzynarodowym, „Państwo i Prawo” 2011, nr 2, s. 84 i nast.

${ }^{126}$ E. Łętowska, J. Woleński, Instytucjonalizacja związków partnerskich a Konstytucja $R P$ z 1997 r., „Państwo i Prawo” 2013, nr 6, s. 15 i nast.

${ }^{127}$ K. Święch, Pozycja..., Lex/el.

${ }^{128}$ W. Skrzydło, Konstytucja..., Lex/el; T. Smyczyński, Ochrona rodziny w Konstytucji $R P$, „Państwo i Prawo” 1994, nr 2, s. 4 i nast.; tenże, Rodzina i prawo rodzinne w świetle nowej Konstytucji, „Państwo i Prawo” 1997, nr 11-12, s. 187. 
tucja jednoznacznie rozstrzyga tę kwestię, stanowiąc, iż tylko związek kobiety i mężczyzny jest prawnie uznawany przez państwo i tylko taki związek korzysta z ochrony i opieki Rzeczypospolitej"129, zasługując na ochronę i wsparcie - także „instrumentami podatkowymi”"130, pamiętając że także prawo podatkowe - na wzór zaleceń płynących również z Pisma Świętego - opowiada się za preferencjami (nie tylko podatkowymi) zastrzeżonymi wyłącznie dla węzła małżeńskiego ${ }^{131}$, a nie związków partnerskich, np. konkubinatów ${ }^{132}$.

W świetle powyższego przyjąć należy, że ustawodawca powinien przyznawać preferencje podatkowe jedynie małżonkom, czyli kobiecie i mężczyźnie pozostającym w związku określonym w art. 18 Konstytucji RP ${ }^{133}$ i Kodeksie rodzinnym i opiekuńczym ${ }^{134}$, gdzie istota małżeństwa została w sposób dostateczny uregulowana w przepisach art. 1 i nast. Także Trybunał Konstytucyjny całkowicie podziela wyrażoną w tym względzie ocenę, którą wielokrotnie akcentował, zauważając, że władza ustawodawcza dysponuje daleko idącą swobodą w kształtowaniu systemu podatkowego, w ramach której może decydować, m.in. o ulgach i zwolnieniach podatkowych. Niemniej jednak ustanawianie odstępstw od zasady powszechności opodatkowania musi być usprawiedliwione celami społeczno-gospodarczymi, odzwierciedlonymi w systemie konstytucyjnie chronionych wartości, a takimi jest na pewno wspieranie małżeństw, a szerzej rodziny ${ }^{135}$. W innym wyroku podniesiono także słuszną tezę, że

„jednym z najważniejszych kryteriów wyznaczających zakres zdolności płatniczej jest sytuacja rodzinna podatnika. Jest bowiem oczywiste, że podatnik mający na utrzymaniu małżonka zaspokoi z takiego samego dochodu mniej potrzeb niż podatnik samotny, a podatnik mający na utrzymaniu dzieci - mniej potrzeb niż podatnik bezdzietny. Rozwiązania uwzględniające sytuację rodzinną podatnika uzasadniają zatem wprowadzenie odstępstw od powszechności opodatkowania, gdyż osoby mające na

\section{${ }^{129}$ Ibidem.}

${ }^{130} \mathrm{~J}$. Nikołajew, G. Leśniewska, Rola rodziny w kształtowaniu społeczeństwa obywatelskiego, „Management and Business Administration. Central Europe” 2012, nr 2, s. 123 i nast.

${ }^{131}$ M. Zubik, Podmioty konstytucyjnych wolności, praw i obowiązków, „Przegląd Legislacyjny" 2007, nr 2, s. 41.

${ }^{132}$ M. Klink, Instytucja..., s. 477-478.

${ }^{133}$ A. Siostrzonek-Sergiel, Kilka uwag na temat zakresu konstytucyjnej ochrony rodziny, „Monitor Prawniczy” 2015, nr 23, s. 1254 i nast.

${ }^{134}$ Wyrok WSA w Gdańsku z dnia 27 kwietnia 2010 r., I SA/Gd 99/10, CBOSA.

${ }^{135}$ Wyrok TK z dnia 9 maja 2005 r., SK 14/04, Lex/el; wyrok TK z dnia 12 kwietnia 2011 r., SK 62/08, Lex/el. 
utrzymaniu dzieci znajdują się w odmiennej sytuacji niż osoby, które dzieci nie posiadają. Stanowi to również konsekwencję zasady sprawiedliwości podatkowej”136.

Wieloletnie zaniechania państwa polskiego w zakresie polityki prorodzinnej doprowadziły do swoistych patologii, m.in. system różnego rodzaju „zasiłków socjalnych”, spowodował „wysyp” związków niemałżeńskich i pozamałżeńskich dzieci - przez co małżeństwo stało się instytucją mniej korzystną ekonomicznie ${ }^{137}$. Zatem popularność „wolnych związków” to nie tylko efekt rewolucji obyczajowej, ale „spryt ekonomiczny” i dowód na ich sui generis "przedsiębiorczośćc"138, przez co nie można mówić o kryzysie małżeństwa, ale raczej o kryzysie charakterów i postaw ludzkich ${ }^{139}$.

Wzrastająca fala rozwodowa, ale także niezawieranie małżeństw ${ }^{140}$, staje się „plagą społeczną”, nie bez znaczenia dla funkcjonowania państwa ${ }^{141}$. Zatem małżeństwo potrzebuje pilnego i kompleksowego wsparcia systemowego, w tym również podatkowego ${ }^{142}$, dlatego też trzeba je traktować jako inwestycję w przyszłość ${ }^{143}$, gdzie zasadniczą kwestię odegra stworzenie prorodzinnego systemu podatkowego ${ }^{144}$. Przyjąć więc należy, że z mał-

${ }^{136}$ Wyrok TK z dnia 12 kwietnia 2011 r., SK 62/08, Lex/el.

137 Informacja Najwyższej Izby Kontroli, pt. Koordynacja polityki rodzinnej w Polsce, https://www.nik.gov.pl/plik/id,9100,vp,11306.pdf; wywiad z dr P. Szukalskim, demografem badającym przemiany polskiej rodziny - www.wiadomosci.wp.

${ }^{138}$ Ibidem.

139 Z. Łyko, Nauki..., s. 585; P. Bosmans, Szczęście na cały rok, Wrocław 2001.

${ }^{140}$ Zob. Osoby niezamężne i nieżonate w polskich rodzinach, Centrum Badania Opinii Społecznej, https://cbos.pl/SPISKOM.POL/2017/K_093_17.PDF; M. Szyszka (red.), Rodzina polska. Wybrane aspekty funkcjonowania, https://docplayer.pl/5135994-Rodzina-polska-wybrane-aspekty-funkcjonowania.html.

${ }^{141}$ I. Nowak, Wspólne..., s. 229-230.

142 Zob. tezy z konferencji, pt. „Wsparcie rodzin z dziećmi na utrzymaniu w rozwiązaniach dotyczących podatku dochodowego od osób fizycznych jako element polityki rodzinnej państwa", która odbyła się 26 marca 2014 r., w Ministerstwie Pracy i Polityki Społecznej, http://www. mpips.gov.pl/aktualnosci-wszystkie/art,5538,6643, podatkowe-wsparcie-dla-polskich-rodzin. html; A. Gomułowicz, J. Małecki, Ustawa..., Lex/el.; I. Nowak, Przychody..., s. 189-212.

${ }^{143}$ Zob. I.E. Kotowska (red.), Dobry Klimat dla rodziny. Program polityki rodzinnej Prezydenta RP 2013, Warszawa 2013, http://www.prezydent.pl/dla-rodziny/program-polityki-rodzinnej-prezydenta-rp/; M. Myck, M. Kundera, M. Oczkowska, Finansowe wsparcie rodzin w Polsce: obecny system i przykłady modyfikacji w systemie podatkowym, http:// www.prezydent.pl/dla-rodziny/kwota-wolna-od-podatku/; szerzej T. Kardach, M. Karlikowska, Ulgi rodzinne w podatkach dochodowych od osób fizycznych w wybranych państwach OECD, „Kwartalnik Prawa Podatkowego” 2001, nr 3-4, s. 57 i nast.

${ }^{144}$ W. Wójtowicz, Kontrowersje wokót „prorodzinności” systemu podatkowego, „Kwartalnik Prawa Podatkowego" 2000, nr 2, s. 64; B. Komorowski, Rodzinę trzeba traktować jako 
żeństwem powinno być jak z przyzwoitością - może się nie opłaca w sensie ekonomicznym - ale warto je wspierać i wspomagać ${ }^{145}$, np. „mechanizmami podatkowoprawnymi".

\section{BIBLIOGRAFIA}

Babiarz S., Komentarz do art. 111 o.p., [w:] S. Babiarz, B. Dauter, B. Gruszczyński, R. Hauser, A. Kabat, M. Niezgódka-Medek, J. Rudowski, Ordynacja podatkowa. Komentarz, Warszawa 2017, Lex/el.

Babiarz S., Spadek i darowizna w prawie cywilnym i podatkowym, Warszawa 2012.

Babiarz S., Mariański A., Nykiel W., Ustawa o podatku od spadków i darowizn. Komentarz, Warszawa 2010.

Bała P., Invocatio dei w Konstytucji RP z 2 kwietnia 1997 r. w perspektywie porównawczej $i$ historycznej, http://www.bibliotekacyfrowa.pl/Content/39049/016.pdf.

Banach J., Zwolnienie z podatku od spadków i darowizn nabycia własności rzeczy lub praw majątkowych przez osoby najbliższe, „Biuletyn Skarbowy” 2009, nr 6.

Banaszak B., Konstytucja Rzeczypospolitej Polskiej. Komentarz 2012, Legalis/el.

Banaszak B., Zieliński M., Konstytucyjne i ustawowe pojęcie rodziny, „,Monitor Prawniczy” 2014, nr 7.

Banaszkiewicz B., „Małżeństwo jako związek kobiety i mężczyzny”. O niektórych implikacjach art. 18 Konstytucji RP, „Kwartalnik Prawa Prywatnego” 2013, nr 3.

Banaszkiewicz B., Problem konstytucyjnej oceny instytucjonalizacji związków homoseksualnych, „Kwartalnik Prawa Prywatnego” 2004, nr 2.

Bartosiewicz A., Pojęcie podatnika w świetle przepisów Ordynacji podatkowej, „Kwartalnik Prawa Podatkowego" 2009, nr 3-4.

Biblia Ekumeniczna, Towarzystwo Biblijne w Polsce, Warszawa 2017.

Biegalski A., Petnomocnik strony w postępowaniu podatkowym, „Prawo i Podatki” 2009, nr 8. Biel S., Biel K., Kobiety między miłością a zdradą. Medytacje biblijne, Kraków 2012.

Błaszczyk A., Podatek od spadków i darowizn - zwolnienie nabycia rzeczy i praw majątkowych przez osoby najblizsze, [w:] J. Glumińska-Pawlic (red.), Doradca podatkowy obrońca praw podatnika, Katowice 2008.

Boć J. (red.), Konstytucje Rzeczypospolitej oraz komentarz do Konstytucji RP z 1997 roku, Wrocław 1998.

inwestycje, http://www.prezydent.pl/aktualnosci/wizyty-krajowe/art,348,rodzine-trzeba-traktowac-jako-inwestycje.html; idem, Rodzina ma strategiczne znaczenie i potrzebuje wsparcia, http://wiadomosci.onet.pl/kraj/prezydent-rodzina-ma-strategiczne-znaczenie-i-potrzebuje-wsparcia/drz2v.

${ }^{145}$ Zob. M. Masior, Wplyw uregulowań prawnopodatkowych na ochronę rodziny, „Kwartalnik Prawa Podatkowego" 2015, nr 2, s. 93 i nast.; B. Komorowski, $Z$ wielodzietnościa jak z przyzwoitością. Nie opłaca się, ale warto, http://www.tvn24.pl/wiadomosci-z-kraju,3/komorowski-z-wielodzietnoscia-jak-z-przyzwoitoscia-nie-oplaca-sie-ale-warto,431126.html. 
Bogucki S., Komentarz do art. 9 pkt 10 lit. b) u.p.c.c., [w:] S. Bogucki, A. Dumas, W. Stachurski, K. Winiarski, Podatek od czynności cywilnoprawnych. Komentarz dla praktyków, Gdańsk 2014.

Bogucki S., Cudak A., Pietrasz P., Stachurski W., Winiarski K., Wrzesińska-Nowacka A., Podatek od spadków i darowizn. Komentarz, Gdańsk 2015.

Borkowski J., Adamiak B., Komentarz do art. 33 k.p.a., [w:] B. Adamiak, J. Borkowski, Kodeks postępowania administracyjnego. Komentarz 2017, Legalis/el.

Borkowski J., Adamiak B., Komentarz do art. 138 b.p., [w:] B. Adamiak, J. Borkowski, P. Borszowski, R. Mastalski, J. Zubrzycki, Ordynacja podatkowa. Komentarz 2017, Wrocław 2017.

Borszowski P., Komentarz do art. $4 a$ u.p.s.d., [w:] P. Borszowski, J. Wantoch-Rekowski, A. Nita, K. Stelmaszczyk, K. Musiał, Ustawa o podatku od spadków i darowizn. Komentarz 2017, Lex/el.

Borysiak W., Komentarz do art. 18 Konstytucji RP, [w:] M. Safan, L. Bosek (red.), Konstytucja RP. Tom I. Komentarz do art. 1-86 (2016), Legalis/el.

Bosmans P., Szczęście na cały rok, Wrocław 2001.

Brzeziński B., Glosa do wyroku NSA z dnia 21 lutego 2001 r., I SA/Gd 1012/99, „Przegląd Orzecznictwa Podatkowego" 2002, nr 3.

Brzeziński B., Jezierski J., Konkubinat a polskie prawo podatkowe, „Nowe Prawo” 1990, nr 4-6.

Brzeziński B., Jezierski J., Pozycja rodziny w polskim prawie podatkowym, [w:] J. Głuchowski (red.), Studia podatkowe, Torun 1991.

Brzeziński B., Olesińska A., Zagadnienia odpowiedzialności w prawie podatkowym, [w:] B. Brzeziński, A. Olesińska, J. Pustuł (red.), Odpowiedzialność i sankcje w prawie podatkowym, Toruń 2017.

Chustecka K., Podatek od spadków i darowizn. Praktyka i orzecznictwo, Warszawa 2010.

Dębowska-Romanowska T., O pojęciu i skutkach „wniosku wyrażonego we wspólnym zeznaniu rocznym" o łączne opodatkowanie małżonków - w rozumieniu art. 6 ust. 2 ustawy o podatku dochodowym od osób fizycznych, [w:] Regulacje prawno-podatkowe i rozwiązania finansowe. Pro publico bono. Ksiega jubileuszowa Profesora Jan Gtuchowskiego, Toruń 2002.

Dowgier R., Komentarz do art. 111 o.p., [w:] L. Etel (red.), Ordynacja podatkowa. Komentarz aktualizowany 2018, Lex/el.

Etel L. (red.), Prawo podatkowe. Zarys wykładu, Warszawa 2013.

Filipczyk H., Podatek od czynności cywilnoprawnych. Komentarz 2015, Lex/el.

Goettel A., Kontrowersje wokół przesłanek zwolnienia od podatku pożyczek udzielanych osobom bliskim (na kanwie wyroku sądu administracyjnego), „Monitor Podatkowy” 2011, nr 6.

Goettel A., Podatkowoprawne skutki zawarcia i ustania małżństwa 2016, Lex/el.

Goettel M., Niektóre aspekty wspólnego opodatkowania małżonków, „Przegląd Podatkowy" 2001, nr 4.

Goettel M. (red.), Lemonnier M. (red.), Goettel A., Orłowski J., Pahl B., Tyrakowski M., Wardencka K., Zięty J.J., Instytucje prawa cywilnego w konstrukcji prawnej podatków 2011, Lex/el. 
Gołaszewski P., Komentarz do art. 33 k.p.a., [w:] R. Hauser, M. Wierzbowski (red.), Kodeks postępowania administracyjnego. Komentarz 2018, Legalis/el.

Gomułowicz A., Małecki J., Podatki i prawo podatkowe 2006, Lex/el.

Gomułowicz A., Małecki J., Ustawa o podatku dochodowym od osób fizycznych. Komentarz 2003, Lex/el.

Górczak K., Konkubent zapłaci podatek i od darowizn, i od spadku, http://podatki.gazetaprawna.pl/artykuly/401357,konkubent_zaplaci_podatek_i_od_darowizn_i_od_ spadku.html.

Halberda J., Zniesienie separacji, „Rejent” 2004, nr 2.

Ignaczak K., Komentarz do art. $138 b$ o.p., [w:] H. Dzwonkowski (red.), Ordynacja podatkowa. Komentarz 2018, Legalis/el.

Jaklewicz T., Konstytucyjne prawa wierzacych, https://www.gosc.pl/doc/2142934.Konstytucyjne-prawa-wierzacych.

Kabat A., Komentarz do art. $138 b$ o.p., [w:] S. Babiarz, B. Dauter, B. Gruszczyński, R. Hauser, A. Kabat, M. Niezgódka-Medek, J. Rudowski, Ordynacja podatkowa. Komentarz, Warszawa 2017, Lex/el.

Kardach T., Karlikowska M., Ulgi rodzinne w podatkach dochodowych od osób fizycznych w wybranych państwach OECD, „Kwartalnik Prawa Podatkowego” 2001, nr 3-4.

Karwat P., Jak uniknać nieporozumień z organami podatkowymi przy ustanawianiu i odwoływaniu pełnomocnictwa?, „Prawo i Podatki” 2006, nr 4.

Kędziora R., Kodeks postępowania administracyjnego. Komentarz 2017, Legalis/el.

Klink M., Instytucja małżeństwa w polskim prawie podatkowym, [w:] I. Czaja-Hliniak (red.), Nauka prawa finansowego po I dekadzie XXI wieku. Ksiega pamiątkowa dedykowana Profesorowi Apoloniuszowi Kosteckiemu, Kraków 2012.

Kolendowicz R., Podmiotowość podatkowoprawna przy konstrukcji łącznego opodatkowania dochodów małżonków, „Kwartalnik Prawa Podatkowego” 2012, nr 4.

Komorowski B., Rodzina ma strategiczne znaczenie i potrzebuje wsparcia, http://wiadomosci.onet.pl/kraj/prezydent-rodzina-ma-strategiczne-znaczenie-i-potrzebuje-wsparcia/drz2v.

Komorowski B., Rodzinę trzeba traktować jako inwestycję, http://www.prezydent.pl/aktualnosci/wizyty-krajowe/art,348,rodzine-trzeba-traktowac-jako-inwestycje.html.

Komorowski B., Z wielodzietnościa jak z przyzwoitością. Nie opłaca się, ale warto, http:// www.tvn24.pl/wiadomosci-z-kraju,3/komorowski-z-wielodzietnoscia-jak-z-przyzwoitoscia-nie-oplaca-sie-ale-warto,431126.html.

Koperkiewicz-Mordel K., Podatek dochodowy od osób fizycznych, [w:] M. Sęk (red.), Prawo podatkowe. Podręcznik dla Podyplomowego Studium Prawa Podatkowego, t. 2, Łódź 2014.

Koperkiewicz-Mordel K., Podatek od spadków i darowizn, [w:] W. Nykiel (red.), Prawo podatkowe w Polsce. Podręcznik akademicki, Warszawa 2018.

Kostecki A., Podmiotowość podatkowa małżonków, „Państwo i Prawo” 1965, nr 1.

Kotowska I.E. (red.), Dobry Klimat dla rodziny. Program polityki rodzinnej Prezydenta RP 2013, Warszawa 2013.

Kowalski G., Założenia prawa rodzinnego w świetle Konstytucji Rzeczypospolitej Polskiej, [w:] P. Kasprzyk, P. Wiśniewski (red.), Prawo rodzinne w dobie przemian, Lublin 2009. 
Kukulski Z., Komentarz do art. 6 u.p.d.o.f., [w:] W. Nykiel, A. Mariański (red.), Komentarz do ustawy o podatku dochodowym od osób fizycznych 2015, Gdańsk 2015.

Kukulski Z., Strzelec D., Prawo podatkowe, Warszawa 2012.

Litwińczuk H., Opodatkowanie rodziny, Warszawa 1989.

Łętowska E., Woleński J., Instytucjonalizacja związków partnerskich a Konstytucja RP $z 1997$ r., „Państwo i Prawo” 2013, nr 6.

Łyko Z., Nauki Pisma Świętego, Warszawa 1989.

Majewicz M., Opodatkowanie dochodów rodziny w Polsce w latach 1992-1994, Warszawa 1994.

Malarski R., Zdanie odrębne do uchwały SN z dnia 25 lutego 2016 r., I KZP 20/15, Lex/el.

Mariański A., O potrzebie zmiany praktyki stosowania prawa podatkowego. Glosa do wyroku TK z dnia 18 lipca 2013 r., (SK 18/09), „Monitor Podatkowy” 2013, nr 11.

Mariański A., Odpowiedzialność osób trzecich za zobowiązania. Podstawy i wyłączenia, Gdańsk 2004.

Masior M., Wpływ uregulowań prawnopodatkowych na ochronę rodziny, „Kwartalnik Prawa Podatkowego" 2015, nr 2.

Mastalski R., Prawo podatkowe, Warszawa 2012.

Matan A., Zastępstwo procesowe w ogólnym postępowaniu administracyjnym, Katowice 2001.

Matyszewska E., Darowizny między matżonkami: po separacji tė̇ jest ulga podatkowa, http://podatki.gazetaprawna.pl/artykuly/346338,darowizny_miedzy_malzonkami_ po_separacji_tez_jest_ulga_podatkowa.html.

Musiał K., Komentarz do art. 4 u.p.s.d., [w:] P. Borszowski, J. Wantoch-Rekowski, A. Nita, K. Stelmaszczyk, Ustawa o podatku od spadków i darowizn. Komentarz 2017, Lex/el.

Münnich M., Małżonkowie jako strona procedur podatkowych uregulowanych w Ordynacji podatkowej, [w:] M. Popławski (red.), Ordynacja podatkowa. Zagadnienia proceduralne, Białystok 2011.

Myck M., Kundera M., Oczkowska M., Finansowe wsparcie rodzin w Polsce: obecny system i przykłady modyfikacji w systemie podatkowym, http://www.prezydent.pl/dla-rodziny/kwota-wolna-od-podatku/.

Nikołajew J., Leśniewska G., Rola rodziny w kształtowaniu społeczeństwa obywatelskiego, „Management and Business Administration. Central Europe” 2012, nr 2.

Nowak I., Obowiązek alimentacyjny a prawo podatkowe - wybrane aspekty, „Toruński Rocznik Podatkowy" 2015/el.

Nowak I., Opodatkowanie alimentów, [w:] J.M. Łukasiewicz, I. Ramus (red.), Prawo alimentacyjne. Zagadnienia systemowe i proceduralne, t. I, Torun 2015.

Nowak I., Podatek od spadków i darowizn, [w:] M. Sęk (red.), Prawo podatkowe. Podręcznik dla Podyplomowego Studium Prawa Podatkowego, t. 3, Łódź 2014.

Nowak I., Przychody ze stosunku pracy a wspólne opodatkowanie matżonków, [w:] R. Frey (red.), Świadczenie pracy jako przedmiot zobowiązania umownego, Kielce 2013.

Nowak I., Skutki pominięcia petnomocnika w sprawie podatkowej, [w:] R. Frey (red.), Przemiany prawa publicznego i prywatnego na poczatku XXI wieku, Kielce 2012.

Nowak I., Udzielenie pełnomocnictwa a jego cofnięcie $w$ postępowaniu podatkowym - wybrane aspekty, „Przegląd Podatków Lokalnych i Finansów Samorządowych” 2013, nr 2.

Nowak I., Wspólne opodatkowanie małżonków na gruncie podatku dochodowego od osób fizycznych - postulaty de lege lata i de lege ferenda, [w:] B. Kucia-Guściora, M. Mün- 
nich, A. Zdunek (red.), Stanowienie i stosowanie prawa podatkowego w Polsce. Sankcje i preferencje w prawie podatkowym, Lublin 2015.

Nowak I., Zwolnienie dla osób najbliższych na podstawie art. 4a ustawy o podatku od spadków i darowizn w świetle orzecznictwa i pogląów doktryny, „Toruński Rocznik Podatkowy" 2012/el.

Nowak I., Rutkowski B., Petnomocnictwo $w$ świetle ordynacji podatkowej - stan obecny a planowane zmiany, „Toruński Rocznik Podatkowy” 2014/el.

Nykiel A., Podmiotowość podatkowoprawna. Wybrane zagadnienia, „Państwo i Prawo” 2000, nr 3.

Nykiel W., Ulgi i zwolnienia w konstrukcji prawnej podatku, Warszawa 2002.

Ofiarski Z., Ogólne prawo podatkowe. Zagadnienia materialnoprawne i proceduralne 2013, Lex/el.

Ofiarski Z., Ustawa o opłacie skarbowej. Ustawa o podatku od czynności cywilnoprawnych. Komentarz 2018, Lex/el.

Olesińska A., Odpowiedzialność osób trzecich za zobowiązania podatkowe, Lubin 2000.

Olesińska A., Polskie prawo podatkowe. Zarys systemu, Toruń 2012.

Olesińska A., Wspólność majątkowa matżeńska a ogólne prawo podatkowe, [w:] Regulacje prawnopodatkowe i rozwiązania finansowe. Pro publico bono. Ksiega jubileuszowa Profesora Jana Głuchowskiego, Torun 2002.

Olesińska A., Pustuł J. (red.), Odpowiedzialność i sankcje w prawie podatkowym, Torun 2017.

Pilich M., Związki quasi-matżeńskie $w$ polskim prawie prywatnym międzynarodowym, „Państwo i Prawo” 2011, nr 2.

Pomorski P., Podatek dochodowy od osób fizycznych, [w:] P. Smoleń, W. Wójtowicz (red.), Prawo podatkowe, Warszawa 2017.

Rusinek M., Podatek od spadków i darowizn. Komentarz do zmian wprowadzonych ustawa $z$ dnia 16 listopada 2006 r. o zmianie ustawy o podatku od spadków i darowizn oraz ustawy o podatku od czynności cywilnoprawnych, Lex/el.

Siostrzonek-Sergiel A., Kilka uwag na temat zakresu konstytucyjnej ochrony rodziny, „Monitor Prawniczy" 2015, nr 23.

Skrzydło W., Konstytucja Rzeczypospolitej Polskiej. Komentarz 2013, Lex/el.

Słotwińska-Rosłanowska E., Zmiana demograficznego modelu rodziny a ewolucja prawa rodzinnego w kontekście kohabitacji w Europie, „Zeszyty Naukowe Uniwersytetu Ekonomicznego w Katowicach" 2017, nr 309.

Smoleń P., Kształtowanie obciążenia w podatku od spadków i darowizn, Lublin 2006.

Smyczyński T., Ochrona rodziny w Konstytucji RP, „Państwo i Prawo” 1994, nr 2.

Smyczyński T., Rodzina i prawo rodzinne w świetle nowej Konstytucji, „Państwo i Prawo” 1997, nr 11-12.

Stachurski W., Komentarz do art. $138 b$ o.p., [w:] L. Etel (red.), Ordynacja podatkowa. Komentarz 2017, Lex/el.

Stachurski W., Komentarz do art. $138 b$ o.p., [w:] L. Etel (red.), Ordynacja podatkowa. Komentarz aktualizowany 2018, Lex/el.

Stachurski W., Komentarz do art. 4a. u.p.s.d., [w:] S. Bogucki, A. Cudak, P. Pietrasz, W. Stachurski, K. Winiarski, A. Wrzesińska-Nowacka, Podatek od spadków i darowizn. Komentarz, Gdańsk 2015.

Startek K., Pełnomocnictwo w prawie podatkowym, „Przegląd Podatkowy” 2008, nr 5. 
Stefaniuk M., Preambuła do Konstytucji RP z 2 kwietnia 1997 roku w orzecznictwie Trybunału Konstytucyjnego, „Annales Universitatis Mariae Curie-Skłodowska Lublin-Polonia Sectio g", 2003/2004, vol. L/LI.

Strus Z., Znaczenie artykułu 18 Konstytucji Rzeczypospolitej Polskie, „Palestra” 2014, nr 9. Szyszka M. (red.), Rodzina polska. Wybrane aspekty funkcjonowania, https://docplayer. pl/5135994-Rodzina-polska-wybrane-aspekty-funkcjonowania.html.

Świaczny S., Nierozerwalność małżeństwa a rozwiązanie małżéstwa naturalnego w prawie kanonicznym, Katowice 2004.

Święch K., Pozycja rodziny w polskim prawie podatkowym 2013, Lex/el.

Tarka A., Konkubenci na oku fiskusa, http://www.rp.pl/artykul/793727,890055-Podatek-od-darowizny-w-konkubinacie.html.

Winczorek P., Komentarz do Konstytucji Rzeczypospolitej Polskiej z dnia 2 kwietnia 1997 r., Warszawa 2008.

Wojewoda M., Matżeństwa jednopłciowe i związki partnerskie w polskim rejestrze stanu cywilnego?, „Studia Prawno-Ekonomiczne” 2017, t. CIII.

Wójtowicz W., Kontrowersje wokół „prorodzinności” systemu podatkowego, „Kwartalnik Prawa Podatkowego" 2000, nr 2.

Wójtowicz W., Problem „prorodzinności” podatku dochodowego od osób fizycznych, [w:] T. Dębowska-Romanowska, A. Jankiewicz (red.), Konstytucja, ustrój, system finansowy państwa. Księga pamiątkowa ku czci Profesor Natalii Gajl, Warszawa 1999.

Wójtowicz W., Teoretyczne modele opodatkowania dochodów osób fizycznych, [w:] P. Smoleń, W. Wójtowicz (red.), Prawo podatkowe, Warszawa 2017.

Wójtowicz W., Smoleń P., Podatek dochodowy od osób fizycznych - prorodzinny czy neutralny, Warszawa 1999.

Zubik M., Podmioty konstytucyjnych wolności, praw i obowiązków, „Przegląd Legislacyjny" 2007, nr 2.

http://www.prezydent.pl/dla-rodziny/program-polityki-rodzinnej-prezydenta-rp/.

Summary. The paper addresses the problem of the position of marriage on the basis of selected regulations of the Polish tax law in relation to the so-called "partnerships". The author showed that in the light of Article 18 of the Constitution of the Republic of Poland, marriage is a relationship between a woman and a man (a monogamous union of persons of different sex), placed under the protection and care of the Republic of Poland and constituting the so-called autonomous constitutional value. It should be deduced from this that also in the area of Polish tax law there is no legal basis for equating partnerships (heterosexual or homosexual) with marriage. Therefore, only marriage enjoys tax preferences, because the legislator prefers it as the basis of family relations as opposed to partnerships, which are only a category of facts, not a legal institution. In addition, according to the Author, marriage needs urgent and comprehensive system support, including tax support, because marriage should be like decency - maybe it does not pay in the economic sense - but it is worth supporting and aiding, for example, by means of "tax-law mechanisms".

Keywords: marriage, common-law marriage, partnerships, tax law, taxes, tax preferences. 